\title{
POLITICIZED JUDICIAL REVIEW IN ADMINISTRATIVE LAW: THREE IMPROBABLE RESPONSES
}

\author{
Sidney A. Shapiro* and Richard Murphy**
}

\begin{abstract}
In the public discourse about the courts, the claims of legal realism are simultaneously proclaimed from the rooftops and disavowed in the streets. The American judiciary is said to be squarely situated in politics, yet is not, somehow, thought to be entirely of politics. ${ }^{1}$
\end{abstract}

Who are you going to believe, me or your own eyes? ${ }^{2}$

I've been there I know the way (Can't get there from here). ${ }^{3}$

\section{INTRODUCTION}

In the United States, politics demands that judges at their confirmation hearings never admit that they make political decisions from the bench. Following Blackstone, rather than make law, they insist that they merely find and apply it. ${ }^{4}$ Judges from both sides of the political aisle must follow this eighteenth-century script. Thus, during his confirmation hearing, Chief Justice Roberts explained that it is his homely job "to call balls and strikes" rather than play (political) ball himself." Justice Sotomayor, avoiding the

* University Distinguished Chair in Law, Associate Dean for Research and Development, Wake Forest University School of Law.

** AT\&T Professor of Law, Texas Tech University School of Law. Professors Shapiro and Murphy presented a version of this Article at the 2010 Global Issues Fonum (Administrative Law), held at the University of Aix-en-Provence, Aix-en-Provence, and at the 2010 Fall Meeting of the Administrative Law \& Regulatory Practice Section of the American Bar Association, Washington, D.C. We are indebted to the attendees at both presentations for useful comments and suggestions. Professor Shapiro also wishes to thank his colleague, Professor Ronald Wright, for his assistance and additional colleagues for their input during a Faculty Development Lunch. Professor Murphy adds thanks to Professor Bryan Camp for his suggestions regarding judicial policy preference disclosures and Professor Lars Winther Christensen of the Texas Tech University Department of Math \& Statistics for reviewing this Article's probability analysis.

1 Keith J. Bybee, All Judges ARe Political-EXCEPT When They Are Not 4 (2010).

2 DUCK SouP (Paramount Pictures 1933).

3 R.E.M., Can't Get There From Here, on FABLES of THE RECONSTRUCTION (I.R.S. Records 1985).

4 See 1 William Blackstone, Commentaries *69 ("[A judge is] sworn to determine, not according to his own private judgment, but according to the known laws and customs of the land; not delegated to pronounce a new law, but to maintain and expound the old one.").

5 Roberts's Opening Statement Before Senate Panel, N.Y. TIMES (Sept. 12, 2005), http://www.nytimes.com/2005/09/12/politics/politicsspecial/12cnd-text-roberts.html (transcript as recorded by New York Times) ("I'll remember that it's my job to call balls and strikes and not pitch or bat."). 
umpire metaphor, testified, "[t]he task of a judge is not to make the law-it is to apply the law." Justice Kagan admitted that it would be misleading to suggest that "law is a kind of robotic enterprise . . . and that there's . . no judgment in the process." Even so, she insisted that, when resolving cases, "[y]ou're looking at law and only at law, not your political preferences, not your personal preferences." 8

The confirmation hearings for Justices Roberts, Sotomayor, and Kagan were Kabuki theater-a highly stylized, ritualistic dance by the senators from each party that bore almost no relationship to the reality of judging in the United States. In evaluating both Justice Sotomayor and Justice Kagan, Republican senators applied a litmus test, asking whether the nominee would apply the law in a neutral fashion; in response, the nominee and her Democratic supporters pledged that she would. For Justice Sotomayor, this exercise required furious backpedaling from a comment she made to law students years before that a "wise Latina woman" might have had experiences that would give her insight that her white male colleagues could never possess. ${ }^{9}$

Of course, the notion that judging can be entirely technocratic and neutral is poppycock-especially when a judge is called upon to interpret and to implement vague, indeterminate law-a category that includes most of the most important bits of the U.S. Constitution. ${ }^{10}$ Judging inevitably involves discretion - a reality that Judge Richard Posner once expressed with the rhetorical query, "What Am I? A Potted Plant?"11 The element of discretion is no less prevalent in administrative law, which presents constitutional issues such as determining the requirements of procedural due process or determining who has constitutional standing to sue in federal court. To resolve such matters, the Supreme Court has deployed madde-

6 Text: Sotomayor's Opening Statement, N.Y. TIMES (July 13, 2009), http://www.nytimes.com/ 2009/07/13/us/politics/13confirm.text.html (prepared statement as released by the White House).

7 Kagan Confirmation Hearings Near End, NAT'L PUB. RADIO (June 30, 2010), http:/www.npr.org/templates/transcript/transcript.php?storyld=128220846 (transcript of All Things Considered).

8 Id.

9 See Charlie Savage, A Judge's View of Judging Is on the Record, N.Y. TIMES (May 14, 2009), http://www.nytimes.com/2009/05/15/us/15judge.html (quoting Sotomayor as having said, "I would hope that a wise Latina woman with the richness of her experiences would more often than not reach a better conclusion than a white male who hasn't lived that life" (internal quotation marks omitted)).

10 The sentence of text to which this footnote is appended makes it official-neither Shapiro nor Murphy will ever be a federal judge.

11 Richard A. Posner, What Am I? A Potted Plant?, NEw RePUBlic, Sept. 28, 1987, at 23, 24 (explaining constitutional interpretation, stating that "[m]any provisions of the Constitution .... are drafted in general terms. This creates flexibility in the face of unforeseen changes, but it also creates the possibility of multiple interpretations, and this possibility is an embarrassment for a theory of judicial legitimacy that denies that judges have any right to exercise discretion"). 
ningly vague, multipart frameworks. ${ }^{12}$ The need to "judge," however, hardly stops at the constitutional waterline. Subconstitutional administrative law, too, is festooned with multipart general tests that open the door for more than one reasonable outcome. ${ }^{13}$

The fact that judges have discretion should come as no surprise, unless you have just landed from Mars and your only point of reference is Senate hearings on judicial appointments. But this fact does not necessarily mean that judging is primarily, or even substantially, motivated by a judge's political preferences. A judge's ideology might only come into play in a limited number of cases in which the judge has maximum discretion. This is the story told by judges themselves, ${ }^{14}$ when they are not denying in confirmation hearings that there is any discretion at all.

Mounting empirical evidence raises doubts about this comforting claim. A long line of studies in the political science literature correlates judicial outcomes with whether the judge was appointed by a Republican or Democratic president-a factor that serves in these studies as a proxy for ideology. ${ }^{15}$ Legal scholars have recently demonstrated that outcomes in administrative law cases are likewise linked to whether a judge was ap-

12 For example, the Court announced a perennially mystifying test for standing in Lujan v. Defenders of Wildlife, 504 U.S. 555 (1992). In Lujan, the Court declared that to demonstrate constitutional standing, a plaintiff must satisfy the requirements of injury-in-fact, causation, and redressability. Id. at 560-61. Courts and commentators have criticized the Lujan test for being too difficult to apply consistently. See, e.g., Richard J. Pierce, Jr., Comment, Lujan v. Defenders of Wildlife: Standing as a Judicially Imposed Limit on Legislative Power, 42 DUKE L.J. 1170, 1188 (1993) ("Because of the multiple opinions and multiple lines of reasoning in [Lujan], it is impossible to predict with confidence the scope and effect of its holding.").

13 For example, in Barnhari v. Walton, 535 U.S. 212 (2002), the Court announced a five-part test for identifying which non-legislative rules deserve deference under Chevron U.S.A. Inc. v. Natural Resources Defense Council, Inc., 467 U.S. 837 (1984). In Barnhart, the Court held that Chevron deference was owed to an interpretative rule because of "the interstitial nature of the legal question, the related expertise of the Agency, the importance of the question to administration of the statute, the complexity of that administration, and the careful consideration the Agency has given the question over a long period of time." Barnhart, 535 U.S. at 222. For criticism of Barnhart, see Krzalic v. Republic Title Co., 314 F.3d 875, 879 (7th Cir. 2002) (characterizing Barnhart as a "thicket"), and Kristen E. Hickman, The Need for Mead: Rejecting Tax Exceptionalism in Judicial Deference, 90 MINN. L. REV. 1537,1587 (2006) (referring to Barnhart's significance as "confusing" (quoting Irving Salem et al., ABA Section of Taxation: Report of the Task Force on Judicial Deference, 57 TAX LAW. 717, 755 (2004)) (internal quotation marks omitted)).

14 See, e.g., Harry T. Edwards \& Michael A. Livermore, Pitfalls of Empirical Studies that Attempt to Understand the Factors Affecting Appellate Decisionmaking, 58 DUKE L.J. 1895, $1898-99$ (2009) (conceding that "personal political or ideological predilections" may "at times" affect judicial decisionmaking, but insisting that many cases are "easy" to decide with clear legal answers and that, in harder cases, "after careful analysis of the relevant legal materials, thoughtful deliberations more often than not lead to a unanimous judgment" (emphases omitted) (third internal quotation marks omitted)).

15 See Thomas J. Miles \& Cass R. Sunstein, The New Legal Realism, 75 U. CHI. L. REv. 831, 83233 (2008) (describing empirical literature in law and political science on judging). 
pointed by a Republican or Democratic president. ${ }^{16}$ If the empirical studies accurately describe judicial behavior, they suggest that the random choice of which judges will hear a case may turn judicial review into an ideological lottery of dubious legitimacy. Moreover, the fact that almost twice as many sitting judges were appointed by Republican presidents than by Democratic presidents ${ }^{17}$ disadvantages litigants that press liberal positions before the courts, such as environmental groups or civil rights groups.

This Article begins in Part I by summarizing some of the evidence linking judges' political and ideological proclivities to administrative law outcomes. Part II then discusses how this evidence fits with various models of judicial decisionmaking (i.e., the attitudinal, strategic, craft, and cognition models). This exercise leads to a set of conclusions in Part III that accords with common experience: law matters to judges, who, by and large, are committed to the craft values of their trade. No matter how strong this loyalty, however, where law is indeterminate, we must expect judges' ideological preferences and worldviews to affect their decisions-whether or not judges are consciously aware of these influences. Administrative law is highly indeterminate; ergo, we should expect judicial review of agency action to be politicized. This degree of politicization cannot be pinned down with utter precision. Notwithstanding this inexactitude, the evidence that politicization occurs is strong enough to justify considering what might be done to counter it.

Part IV finishes by considering three improbable possibilities for reform. ${ }^{18}$ The first possibility contemplates changing administrative law to remove judicial discretion, thereby depriving judges of the decisionmaking freedom needed for politicization to occur. This type of fundamental change in the character of administrative law is highly unlikely, to say the least, and probably undesirable in any event. The second proposal is a spin on the old adage that sunlight is the best disinfectant. It contemplates changing the norms of judging to require judges to openly discuss their political and policy preferences when explaining their administrative law decisions. This sort of change might, in addition to making the decisionmaking process more transparent and truthful, decrease politicization. We admit, however, that there are reasons to doubt this conclusion and, further, that judges likely will not rush to embrace this suggested norm of disclosure. We save our most plausible, least ambitious, and simplest reform for

16 For a summary of the results of some of these studies (as well as citations to them), see infra notes 21-31 and accompanying text and chart.

17 See Rena Steinzor \& Sidney Shapiro, The People's Agents and the Battle to Protect THE AMERICAN PUBlic: SPECIAL INTERESTS, GOVERNMENT, AND THreatS TO HEALTH, SAFETY, AND THE ENVIRONMENT 153-54 (2010) (noting that, as of 2009, judges appointed by Republican presidents outnumbered judges appointed by Democratic presidents 162 to 91 ).

18 Cf. Cass R. Sunstein \& Thomas J. Miles, Depoliticizing Administrative Law, 58 DUKE L.J. 2194, 2197 (2009) (remarking, with a touch of despair, that "while the problem of politicized administrative law is unmistakable, there are serious difficulties with each of the imaginable solutions"). 
last: require five-judge panels for a well-defined set of significant agency actions - e.g., legislative rules with significant economic effects promulgated through notice and comment.

\section{IS THERE A JUDICIAL IDEOLOGICAL LOTTERY?}

According to substantial empirical literature, the outcome of a case often depends in part on whether a Republican or Democratic president appointed the judges. ${ }^{19}$ This Part quickly summarizes evidence for this effect in administrative law cases and then evaluates whether this data justifies the conclusion that these cases are uncomfortably akin to ideological lotteries.

\section{A. The Evidence}

Table 1 presents the results of several studies that correlate whether a judge was appointed by a president who is Republican or Democratic with that judge's votes on key administrative law matters. In Table 1, references to "Republicans" and "Democrats" assume that judges come from the same parties as their appointing presidents. ${ }^{20}$

All of the studies indicate significant differences between how, on average, Republicans and Democrats rule in administrative law cases. Some of these differences are truly remarkable. For instance, one study found that Republicans on the Court of Appeals for the District of Columbia Circuit ("D.C. Circuit") are four times more likely to deny standing to environmental plaintiffs than Democrats are. ${ }^{21}$ For another eye opener, consider that between 1991 and 1995, the probability that a Democratic-majority panel on the D.C. Circuit would vote in favor of a challenge seeking more stringent health-and-safety regulation was $50.3 \%$; the parallel figure for a $\mathrm{Re}$ publican majority panel was a mere $27.8 \% .^{22}$

Another critical lesson from recent empirical work is the importance of "panel effects." How a judge will vote in a case depends in substantial part on who else is sitting on the panel. Of particular note, panels consisting solely of appointees from one party - whether R-R-R or D-D-D-behave more ideologically than mixed panels-whether R-R-D or D-D-R. This point is illustrated by a study in Table 1 that assessed the effects of panel composition on industry challenges to Environmental Protection Agency

19 See Miles \& Sunstein, supra note 15, at 832-33 (describing empirical literature in law and political science on judging).

20 For convenience, this Article uses the same convention in the text.

21 See infra Table 1, Row 1. For ease of reference, full citations are appended in footnotes to the table.

22 See infra Table 1, Row 5. 
("EPA") regulations in the D.C. Circuit. Panels composed of three Republicans voted against industry only $27 \%$ of the time, while 2-1 Republicanmajority panels ${ }^{23}$ voted against industry $55 \%$ of the time. Similarly, panels composed of three Democrats voted against industry $72 \%$ of the time, while 2-1 Democratic-majority panels voted against industry $62 \%$ of the time. ${ }^{24}$

Table 1: Studies of Voting Behavior

\begin{tabular}{|c|c|c|c|c|}
\hline Subject & Scope & Test & Results & $\begin{array}{c}\text { Difference } \\
\text { (Percentage } \\
\text { Points) } \\
\end{array}$ \\
\hline \multirow[t]{2}{*}{$\begin{array}{l}\text { Environmental } \\
\text { Standing }^{25}\end{array}$} & $\begin{array}{l}\text { D.C. Circuit } \\
1992-98\end{array}$ & $\begin{array}{c}\text { Average } \\
\text { percentage of } \\
\text { judges voting to } \\
\text { deny standing to } \\
\text { environmental } \\
\text { plaintiffs } \\
\end{array}$ & $\begin{array}{c}\text { Republicans: } \\
79.2 \% \\
\text { Democrats: } \\
18.2 \%\end{array}$ & 61 \\
\hline & $\begin{array}{c}\text { All Circuits } \\
1992-98\end{array}$ & Same & $\begin{array}{c}\text { Republicans: } \\
43.5 \% \\
\text { Democrats: } \\
11.1 \% \\
\end{array}$ & 32 \\
\hline $\begin{array}{l}\text { Industry } \\
\text { Challenge to } \\
\text { Regulations }^{26}\end{array}$ & $\begin{array}{c}\text { EPA } \\
\text { Regulations } \\
\text { D.C. Circuit } \\
\text { 1970-2002 }\end{array}$ & $\begin{array}{l}\text { Average } \\
\text { percentage of } \\
\text { judges voting to } \\
\text { reject industry } \\
\text { challenge }\end{array}$ & $\begin{array}{c}\text { Republicans: } \\
46 \% \\
\text { Democrats: } \\
64 \%\end{array}$ & 18 \\
\hline
\end{tabular}

23 That is, those containing two Republicans and one Democrat.

24 See infra Table 1, Row 3. For other work indicating that panels with mixed partisan affiliations behave less ideologically than purely partisan panels, see, for example, Frank B. Cross \& Emerson $\mathrm{H}$. Tiller, Judicial Partisanship and Obedience to Legal Doctrine: Whistleblowing on the Federal Courts of Appeals, 107 YALE L.J. 2155, 2173 (1998) (concluding, based on applications of the Chevron doctrine in the D.C. Circuit, that "in practice, a 3-0 majority will be far more driven by partisanship than a 2-1 majority"); Thomas J. Miles \& Cass R. Sunstein, The Real World of Arbitrariness Review, 75 U. CHI. L. REV. 761, 785 (2008) [hereinafter Miles \& Sunstein, The Real World] ("In arbitrariness cases, Democratic appointees show heightened liberal voting on all-Democratic (DDD) panels, just as Republican appointees show heightened conservative voting on all-Republican (RRR) panels.”); Thomas J. Miles \& Cass R. Sunstein, Do Judges Make Regulatory Policy? An Empirical Investigation of Chevron, 73 U. CHI. L. REV. 823, 870-71 (2006) [hereinafter Miles \& Sunstein, Do Judges Make Regulatory Policy?] (concluding, based on federal circuit courts' application of Chevron, that the effects of judges' ideological commitments are substantially stronger for unified as opposed to mixed panels).

25 Richard J. Pierce, Jr., Is Standing Law or Politics?, 77 N.C. L. REV. 1741, 1759-60 (1999).

26 Cass R. Sunstein et al., Ideological Voting on Federal Courts of Appeals: A Preliminary Investigation, 90 VA. L. REV. 301,314 tbl.1, 322 (2004). 


\begin{tabular}{|c|c|c|c|c|}
\hline Subject & Scope & Test & Results & $\begin{array}{c}\text { Difference } \\
\text { (Percentage } \\
\text { Points) }\end{array}$ \\
\hline \multirow{4}{*}{$\begin{array}{l}\text { Percentage of } \\
\text { Cases in } \\
\text { Which } \\
\text { Majority } \\
\text { Voted Against } \\
\text { Industry }^{27}\end{array}$} & \multirow{4}{*}{$\begin{array}{l}\text { EPA } \\
\text { Regulations } \\
\text { D.C. Circuit } \\
1970-2002\end{array}$} & $\begin{array}{c}\text { All-Republican } \\
\text { Panel }\end{array}$ & $27 \%$ & \multirow{2}{*}{45} \\
\hline & & $\begin{array}{c}\text { All-Democratic } \\
\text { Panel }\end{array}$ & $72 \%$ & \\
\hline & & $\begin{array}{c}\text { Republican- } \\
\text { Majority Panel }\end{array}$ & $55 \%$ & \multirow{2}{*}{7} \\
\hline & & $\begin{array}{l}\text { Democratic- } \\
\text { Majority Panel }\end{array}$ & $62 \%$ & \\
\hline $\begin{array}{l}\text { Industry } \\
\text { Procedural } \\
\text { Claim }^{28}\end{array}$ & $\begin{array}{c}\text { EPA } \\
\text { Regulations } \\
\text { D.C. Circuit } \\
1987-93\end{array}$ & $\begin{array}{c}\text { Estimated } \\
\text { probability a panel } \\
\text { with mixed } \\
\text { partisan affiliations } \\
\text { would vote in } \\
\text { favor of industry } \\
\end{array}$ & $\begin{array}{l}\text { Republican } \\
\text { Majority: } \\
54-89 \% \\
\text { Democratic } \\
\text { Majority: } \\
2-13 \% \\
\end{array}$ & $52-76$ \\
\hline \multirow{2}{*}{$\begin{array}{l}\text { Health and } \\
\text { Safety } \\
\text { Regulations }^{29}\end{array}$} & \multirow{2}{*}{$\begin{array}{l}\text { Twenty } \\
\text { Federal } \\
\text { Agencies } \\
\text { D.C. Circuit } \\
\text { 1991-95 }\end{array}$} & \multirow{2}{*}{$\begin{array}{l}\text { Probability of case } \\
\text { outcome favoring } \\
\text { more stringent } \\
\text { Regulation }\end{array}$} & $\begin{array}{c}\text { Republican } \\
\text { Majority: } \\
27.8 \% \\
\end{array}$ & \multirow{2}{*}{22.5} \\
\hline & & & $\begin{array}{c}\text { Democratic } \\
\text { Majority: } \\
50.3 \%\end{array}$ & \\
\hline \multirow{2}{*}{$\begin{array}{l}\text { Rate of } \\
\text { Validation } \\
\text { Under } \\
\text { Arbitrariness } \\
\text { or Substantial } \\
\text { Evidence }^{30}\end{array}$} & \multirow{2}{*}{$\begin{array}{c}\text { EPA \& } \\
\text { NLRB } \\
\text { Decisions } \\
\text { All Circuits } \\
\text { 1989-2005 }\end{array}$} & Liberal Outcomes & $\begin{array}{c}\text { Democrats: } \\
72 \% \\
\text { Republicans: } \\
58 \% \\
\end{array}$ & 14 \\
\hline & & $\begin{array}{l}\text { Conservative } \\
\text { Outcomes }\end{array}$ & $\begin{array}{c}\text { Democrats: } \\
55 \% \\
\text { Republicans: } \\
72 \% \\
\end{array}$ & 17 \\
\hline \multirow{2}{*}{$\begin{array}{l}\text { Rate of } \\
\text { Validation } \\
\text { Under } \\
\text { Chevron }^{31}\end{array}$} & \multirow{2}{*}{$\begin{array}{c}\text { EPA \& } \\
\text { NLRB } \\
\text { Decisions } \\
\text { All Circuits } \\
1989-2005\end{array}$} & Liberal Outcomes & $\begin{array}{c}\text { Democrats: } \\
74 \% \\
\text { Republicans: } \\
60 \% \\
\end{array}$ & 14 \\
\hline & & $\begin{array}{l}\text { Conservative } \\
\text { Outcomes }\end{array}$ & $\begin{array}{c}\text { Democrats: } \\
51 \% \\
\text { Republicans: } \\
70 \% \\
\end{array}$ & 19 \\
\hline
\end{tabular}

27 Id. at 314 tbl.1, 322-23.

28 Richard L. Revesz, Environmental Regulation, Ideology, and the D.C. Circuit, 83 VA. L. REV 1717,1763 \& tbl.14 (1997).

29 Richard L. Revesz, Congressional Influence on Judicial Behavior? An Empirical Examination of Challenges to Agency Action in the D.C. Circuit, 76 N.Y.U. L. REv. 1100, 1104 (2001).

30 Miles \& Sunstein, The Real World, supra note 24 , at 777 \& tbl.1; see also id. at 788 tbl.3 (breaking down the validation rates according to panel composition as well).

31 Miles \& Sunstein, Do Judges Make Regulatory Policy?, supra note 24, at 849 tbl.7. 
This research suggests that even Chevron U.S.A. Inc. v. National Resources Defense Council, Inc., ${ }^{32}$ a decision intended to depoliticize statutory interpretation, ${ }^{33}$ is honored in the breach. Republicans were nineteen percentage points more likely than Democrats to validate an interpretation by the National Labor Relations Board ("NLRB") or the EPA that had a conservative impact. ${ }^{34}$ Conversely, Democrats were fourteen percentage points more likely than Republicans to vote for a construction that had a liberal impact. $^{35}$

One reason that Chevron may not be working as intended is that a majority of the justices on the Supreme Court have decided to take periodic detours around the decision. When Professors Thomas Miles and Cass Sunstein looked at validation rates among Supreme Court justices in cases involving statutory interpretation, they found:

* "The most conservative justices [Justices Rehnquist, Scalia, and Thomas were] 30 percentage points more likely to vote to validate [conservative] agency interpretations ... than to validate [liberal] agency interpretations"; ;6

* The same justices had a validation rate that was "19 percentage points lower" when reviewing interpretations made by agencies in the Clinton Administration, compared to their voting to validate agency interpretations in the two Bush administrations, $;^{37}$ and

* "The more liberal justices [Justices Stevens, Breyer, and Ginsburg were] 27 percentage points more likely to vote to validate [liberal] agency interpretations . . . than to validate [conservative interpretations]." ${ }^{38}$

For a point of comparison, the validation rates of more moderate or swing justices (Justices Kennedy, Souter, and O'Connor) were "less consistently correlated with the ideological content of . . agency decision[s]." 39 The authors of the study concluded:

If judicial decisions under the Chevron framework are assessed in crudely political terms, the voting patterns of Supreme Court justices fit with the conventional groupings of the justices

\footnotetext{
32467 U.S. 837 (1984).

33 See Sunstein \& Miles, supra note 18, at 2196 ("Chevron is naturally read to say that resolution of statutory ambiguities calls for a policy judgment, with the suggestion that such judgments should be made by administrators, not judges." (footnote omitted)).

34 See supra Table 1, Row 6.

35 Id

36 Miles \& Sunstein, Do Judges Make Regulatory Policy?, supra note 24, at 826.

37 Id.

$38 \mathrm{Id}$.

39 Id. at 834.
} 
along political lines-a clear signal that the Chevron framework is not having the disciplining effect that it is supposed to have. ${ }^{40}$

Politicized application of Chevron may be only one part-albeit an important one-of the problem of ideologically motivated manipulation of deference doctrine. Professor William N. Eskridge and Lauren E. Baer have demonstrated that the Court applies a continuum of deference rules, running from very strong deference favoring agency interpretations in foreignaffairs cases to a presumption against agency interpretations in criminal cases. ${ }^{41}$ Moreover, Eskridge and Professor Connor Raso have found that the justices manipulate which of these deference doctrines apply, and this manipulation is correlated with a justice's ideology. ${ }^{42}$ This means "Justices systematically support less deferential regimes for policies with which they disagree." ${ }^{43}$ And once they decide to be less deferential, the "Justices are more likely to vote to overturn policies with which they disagree." $" 44$ To be fair, Raso and Eskridge also found that "the Court's announced policies justifying deference (namely, congressional delegation of lawmaking authority and consistency of agency interpretations over time) significantly influence the Justices' willingness to go along with agency interpretations." ${ }^{\text {"45 }}$ Nevertheless, "the legal bite of deference regimes [was] ad hoc and not entirely predictable." ${ }^{\prime 46}$

\section{B. The Extent of Ideological Voting}

How alarming is the evidence summarized above? We urge that one cannot easily dismiss the evidence of ideological voting, even though a number of methodological issues may have influenced these studies' results.

$40 \quad$ Id. at 826.

41 William N. Eskridge, Jr. \& Lauren E. Baer, The Continuum of Deference: Supreme Court Treatment of Agency Statutory Interpretations from Chevron to Hamdan, 96 GEO. L.J. 1083, 1098-1100 \& tbl.1 (2008).

42 Connor N. Raso \& William N. Eskridge, Jr., Chevron as a Canon, Not a Precedent: An Empirical Study of What Motivates Justices in Agency Deference Cases, 110 CoLuM. L. REv. 1727, 1784 (2010).
43 Id.
44 Id.
$45 I d$. at 1734
46 Id. 


\section{Methodological Issues}

Critics contend that these empirical studies often rely on crude characterizations of judicial work product, making the results open to question. ${ }^{47}$ For instance, these studies typically regard judicial outcomes as dependent variables. Categorizing the data requires an analyst to "code" the outcome of each case. This step calls for a judgment, which can go awry. ${ }^{48}$ Moreover, in cases that dispose of multiple issues, binary coding of outcomes as "conservative" or "liberal" can oversimplify the matters at issue. ${ }^{49}$ As Judge Edwards and Professor Livermore observe, "[i]n an administrative law case ... the court's disposition might include a judgment on standing that appears to be 'conservative,' a judgment on 'arbitrary and capricious' review that appears to be 'liberal,' and a judgment under [Chevron] review that is neither." 50

The second objection does not apply to studies that test only judgments under the arbitrary-and-capricious standard, under Chevron, or under any other single doctrine. More broadly, it is important that analysts have found significant differences in how Republican and Democratic judges vote in many diverse areas. ${ }^{51}$ The consistency of these findings belies attempts to explain them away as the result of coding errors-though such errors undoubtedly occur.

There is also a potential problem with the independent variable-the party of the appointing president may not be an accurate representation of a judge's ideology. In the typical study, the analyst assumes that "Republican" judges (i.e., those appointed by Republican presidents) are "conservative" while "Democratic" judges (i.e., those appointed by Democratic presidents) are "liberal." This assumption, however, does not apply to all judges; a Democratic president may appoint a conservative judge. ${ }^{52}$

More significantly, ideology is a complex concept that simple party identification may not adequately capture..$^{53}$ As Judge Posner points out, a judge's ideology may not spring entirely from his or her political orienta-

47 See, e.g., Edwards \& Livermore, supra note 14, at 1944-50 (criticizing the "crude measure[s] of ideology" as failing on several grounds, and stating that "empirical studies generally are not able to predict much about the effects of extralegal factors on appellate decisionmaking").

48 See id. at 1924-26.

49 Brian Z. Tamanaha, The Distorting Slant in Quantitative Studies of Judging, 50 B.C. L. REV. 685, 738 (2009); see also Edwards \& Livermore, supra note 14, at 1924 (noting the "many possible dispositions of cases decided by the appellate courts").

50 Edwards \& Livermore, supra note 14, at 1925.

51 See supra Table 1 and Part I.A (discussing study results).

52 Edwards \& Livermore, supra note 14, at 1919.

53 See Tamanaha, supra note 49, at 738 ("[T]here are different streams within the 'conservative' and 'liberal' political positions, people hold various combinations of positions, they assign different significances to different issues, and they have different degrees of conviction with respect to issues."). 
tion but instead may be influenced by the judge's "moral" and "religious" values and personal characteristics:

\begin{abstract}
[L]et us consider the sources of a judges' ideologies.... Moral and religious values are among those sources and are in turn the products of upbringing, education, salient life experiences, occupational experiences, and personal characteristics that may determine what experiences a person seeks. Personal characteristics include race, sex, ethnicity, and other innate identifiers of a person, but also temperament, which shapes not only values but also dispositions such as timidity and boldness that influence a person's response to situations. ${ }^{54}$
\end{abstract}

This objection, however, does not dispute that case outcomes are influenced by nonlegal factors, all fitting into the rubric of "ideology." It merely claims that judges are moved by a more complicated set of influences than can be captured by the party affiliation of an appointing president. To the extent that the nonlegal intuitions of the judiciary flow from multiple, complex sources, however, the risk of an outcome-determinative political lottery may be reduced. Although a litigant may face two, or even three, Republican (or Democratic) judges, these judges from the same party may not be influenced in the same way by ideological motivations broadly construed.

\title{
2. The $\$ 64$ Question
}

No one will be surprised that ideology plays a role in judging. Even judicial critics of the empirical studies concede that it does. ${ }^{55}$ But how significant is the influence of ideology? How many case outcomes does it affect?

The short answer is that we do not know. But we do know that, regardless of party affiliation, judges often agree with each other. The Courts of Appeals dispose of a large number of cases, perhaps as many as 80 percent, in unpublished decisions. ${ }^{56}$ Further, a large majority of the published appellate court cases are unanimous, maybe up to 85 percent. ${ }^{57}$ In light of this evidence, Judge Edwards estimates that ideology exerts only a marginal

54 RiChARD A. POSNER, HOW JUDGES THINK 94 (2008).

55 See, e.g., Edwards \& Livermore, supra note 14, at 1899.

56 Id. (noting that unpublished decisions constituted over 80 percent of the decisions made by the appellate courts in 2007). Judge Edwards points out that empirical studies do not include unpublished opinions, an omission that skews the results toward the conclusion that ideology plays a larger role in decisionmaking than it actually does. $I d$. at 1899-1900. If studies included unpublished decisions, disagreements between Republican and Democratic judges would appear as a smaller percentage of all cases, because unpublished decisions are rendered per curiam.

57 See id. at 1899 ("Very few federal courts of appeals decisions include a dissent ...."). This result, however, might reflect an aversion to dissenting, rather than ideological agreement between judges from different parties. See infra notes $62-63$ and accompanying text. 
influence, affecting perhaps 5 to 15 percent of the cases in the D.C. Circuit. $^{58}$

Also, a fairly large number of empirical studies have found that agencies consistently win about $60-70$ percent of judicial appeals. ${ }^{59}$ One might interpret this data as indicating that judges generally defer to agencies, regardless of ideology.

Moreover, some empirical studies support Judge Edwards's claim that ideology plays a limited role. For example, Professor Cross, who examined a very large database of appellate court decisions, found that ideology and outcome were related but that "the measured effect size for ideology is always a fairly small one." ${ }^{60}$ After examining a number of other nonlegal factors and finding little or no correlation, Professor Cross saw his results as demonstrating "the importance of the law in determining judicial outcomes."61

Despite these reassurances, it is hard to dismiss the problem of the judicial ideological lottery. While judges often agree with each other and seldom dissent, this phenomenon may be attributable to dissent aversion, rather than to an absence of ideological disagreement. Dissent aversion exists because dissenting does not generally affect the law, may call more attention to an opinion with which the dissenting judge disagrees, and makes courts less collegial. ${ }^{62}$ The latter impact occurs because "[j]udges do not like to be criticized, to bother having to revise a draft opinion in order to parry any solid punches thrown by the dissent, or, worst of all, to lose the third judge to the dissenter."63

More significantly, while judges from different parties concur in many cases, this agreement does not always extend to controversial cases. The studies consistently indicate that ideology is strongly associated with outcome in ideologically contested areas such as environmental protection, labor law, and sex discrimination-subject areas that commonly arise in administrative law. As Judge Posner notes: "The hotter the issue . . the greater the explanatory power of the political variable." Echoing this evaluation, Professors Miles and Sunstein describe the variance in the voting

\footnotetext{
58 Edwards \& Livermore, supra note 14, at 1898-99.

59 See David Zaring, Reasonable Agencies, 96 VA. L. REV. 135, 171 tbl.1, 173-74 (2010) (citing eight studies of agency validation rates and indicating that agencies won $54-77 \%$ of their cases).

60 Frank B. Cross, Decision Making IN THE U.S. Courts of APPEALS 38 (2007). Cross also found that a number of background factors, including prior employment, religion, race, gender, and wealth, had "relatively little effect" on the outcome of cases. Id. at 92. See also Zaring, supra note 59, at 178 (reviewing substantial-evidence determinations of the D.C. Circuit from 2000-2004 and finding "little-but not zero-evidence of ideologically polarized voting").

61 Cross, supra note 60 , at 228.

62 POSNER, supra note 54, at 32.

63 Id.

$64 I d$ at 23.
} 
patterns of Republican and Democratic judges as the "'Standard Pattern of Judicial Voting,' at least in ideologically contested cases." 65

These results suggest the judicial ideological lottery is alive and well in cases of high political salience, a disquieting thought. The fact that agencies win two-thirds of their cases does not diminish our concern. Since ideology shows up most strongly in controversial cases, this statistic may only indicate that agencies prevail in routine cases. Moreover, the fact that an agency prevails in a case does not necessarily mean that ideology has played no role. A court, for example, may dismiss an appeal by an environmental group attacking an EPA regulation because the group lacks standing. This would count as a win for the agency, but it would not necessarily mean that the judges did not engage in ideological behavior.

\section{MODELS OF JUDICIAL BEHAVIOR}

The impact of ideological decisionmaking on American administrative law in ideologically contested cases seems substantial on any reasonable assessment. In this Part, we consider the possible reasons why. The literature offers four models of judicial behavior that bear on this question: attitudinal, strategic, craft-oriented, and cognitive. Table 2 summarizes the key characteristics of each model.

Table 2: Models of Judicial Behavior

\begin{tabular}{|c|c|c|c|}
\hline Model & $\begin{array}{c}\text { Primary } \\
\text { Motivation } \\
\end{array}$ & $\begin{array}{l}\text { Secondary } \\
\text { Motivation }\end{array}$ & $\begin{array}{c}\text { Source of } \\
\text { Discretion }\end{array}$ \\
\hline Attitudinal & Ideological & & \multirow{2}{*}{$\begin{array}{l}\text { Judges } \\
\text { have life- } \\
\text { time tenure }\end{array}$} \\
\hline Strategic & Ideological & $\begin{array}{c}\text { Strategic } \\
\text { Considerations } \\
\end{array}$ & \\
\hline Craft & Legal & Ideology & \multirow{2}{*}{$\begin{array}{c}\text { Law is } \\
\text { ambiguous }\end{array}$} \\
\hline Cognitive & Legal & Ideology & \\
\hline
\end{tabular}

\section{A. Attitudinal Model}

The initial empirical literature on judging was spurred by the conflicting descriptions of judicial behavior offered by the formalists and realists. ${ }^{66}$ Whereas the formalists understood judicial outcomes to be the product of legal reasoning and precedent, the realists claimed that judicial discretion was very broad and that the law often did not mandate a particular out-

65 Miles \& Sunstein, Do Judges Make Regulatory Policy?, supra note 24, at 838.

66 See Tamanaha, supra note 49 , at 687. 
come. ${ }^{67}$ This conflict led empiricists to hypothesize two models of judicial behavior ${ }^{68}$ Under the formalist model, legal doctrines determine case outcomes; under the attitudinal model, judicial ideological attitudes and values determine case outcomes. ${ }^{69}$ When initial studies found a correlation between judicial ideology and case outcomes, commentators understood the results as disproving legal formalism. ${ }^{70}$

This reading of the evidence was consistent with the professional orientation of the initial empiricists, most of whom were political scientists. As political scientists, they had "a vision of courts as political agencies and judges as political actors," $" 71$ and so they assumed that judges, like other political actors, had a goal of shaping public policy. Political scientists regarded legal doctrine as sufficiently malleable to allow a judge to defend her preferred outcomes. ${ }^{72}$ Thus, judges with life tenure - of course, including all federal judges-could decide cases in an outcome-determinative manner without any substantial fear of reprisal. ${ }^{73}$

Political scientists expressed their skepticism of judges' denials that policy played a role in judging, attributing such claims to institutional selfinterest. Professor Martin Shapiro, for example, suggested that judges could not admit that the formalist model was only a partial description of what they did because they are supposed to apply pre-existing law. ${ }^{74}$ Shapiro continued, "Such is the nature of courts. They must always deny their authority to make law, even when they are making law. One may call this justificatory history, but I call it lying. Courts and judges always lie. Lying

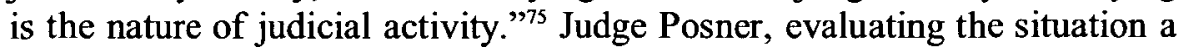
bit more diplomatically, sees judges as "cagey, even coy, in discussing what they do. They tend to parrot an official line about the judicial process (how

67 See id. (describing the difference between formalism and realism, as understood in the early empirical literature). The realists, however, were for the most part not radical skeptics; that is, they did not believe that the outcome of a case turned entirely on the judge's ideology. See Matthew C. Stephenson, Legal Realism for Economists, 23 J. ECON. PERSP. 191, 197 (2009). While they rejected legal formalism as an accurate description of judging, they suggested there are "relatively consistent, stable patterns in judicial decisions, understood (perhaps implicitly) by skilled lawyers, litigants, and judges, that are captured neither by the formal rules nor by crude ideological measures." Id. at 198.

68 Barry Friedman, Taking Law Seriously, 4 PERSP. ON POL. 261, 263 (2006).

69 See Jason J. Czarnezki \& William K. Ford, The Phantom of Philosophy? An Empirical Investigation of Legal Interpretation, 65 MD. L. REV. 841, 847-48 (2006).

70 See id. at 848.

71 Martin Shapiro, Political Jurisprudence, 52 KY. L.J. 294, 296 (1964).

72 Keith E. Whittington, Once More Unto the Breach: PostBehavioralist Approaches to Judicial Politics, 25 LAW \& SOC. INQUIRY 601, 606 (2000).

73 See DAvid W. Rohde \& Harold J. SPAETH, SuPreme Court Decision MAKing 72 (1976); see also Whittington, supra note 72, at 606 (noting that judges have the discretion "to base their decisions solely upon personal policy preferences and the attitudinalist assumption is that they do" (quoting ROHDE \& SPAETH, supra, at 72) (internal quotation marks omitted)).

74 See Martin Shapiro, Judges As Liars, 17 HARV. J.L. \& PUB. POL'Y 155, 155-56 (1994).

75 Id. at 156 
rule-bound it is), and often to believe it, though it does not describe their actual practices." $" 76$

\section{B. Strategic Model}

The new institutionalism in social science contends that individual behavior cannot be analyzed without reference to the role of institutions in influencing that behavior. ${ }^{77}$ Institutionalists therefore assume that judges will act to pursue their policy preferences but will do so strategically. ${ }^{78}$ They contend that judges seek to maximize the effect of those preferences, taking into account institutional constraints that impact the achievement of those objectives. ${ }^{79}$ For Judge Posner, the strategic model is just "common sense," since "whatever a judge wants to accomplish will depend to a considerable degree on other people in the chain of command, broadly understood." 80

To be strategic, judges must be aware of "who the relevant players are, how they are likely to act, and what the consequences of their actions are likely to be." Unlike the attitudinal model, which assumes judges have discretion to pursue their policy preferences, "[t]he strategic model ... considers the judge as dependent upon and responsive to the decisions of her colleagues on the bench and the relative policy positions of other political institutions." 82 The strategic model predicts that judges, aware of potential negative reactions, may reach "a decision that stops short of their ideological preferences if, for example, going too far risks destroying their credibility or inciting a backlash that would retard their objectives." 83

A judge's adherence to precedent can be explained as the product of strategic behavior. As a strategic consideration, a judge will adhere to the norm of stare decisis, even if it is contrary to the judge's policy preference, because other political actors rely on the courts to make decisions that are consistent with existing precedents. Because the system expects judges to base their decisions on prior holdings, "violations of precedent might be costly to a potentially rebellious judge." 84

\footnotetext{
76 POSNER, supra note 54, at 2.

77 See Rogers M. Smith, Political Jurisprudence, the "New Institutionalism," and the Future of Public Law, 82 AM. POL. SCI. ReV. 89, 91 (1988).

78 Whittington, supra note 72 , at 611.

79 Id. at 612 .

80 POSNER, supra note 54, at 29.

81 Whittington, supra note 72 , at 612 .

82 Tracey E. George, Developing a Positive Theory of Decisionmaking on U.S. Courts of Appeals, 58 Oніо ST. L.J. 1635, 1640 (1998).

83 Tamanaha, supra note 49 , at 703.

84 Whittington, supra note 72 , at 612 .
} 
The strategic model has also been employed to explain the differing behavior of judges in uniform and split panels. ${ }^{85}$ Recall that unanimous panels (R-R-R or D-D-D) behave more ideologically than 2-1 majority panels (R-R-D or D-D-R) ${ }^{86}$ According to the strategic model, the two judges in the majority of split panels-the two with the votes to impose their views by force, as it were-will employ strategic considerations in deciding whether or not to accommodate the views of the third judge. ${ }^{87}$ The majority may moderate its approach to avoid the threat that the third judge will act as a whistleblower, calling unwelcome attention to the merits of the majority opinion. ${ }^{88}$ Or the majority judges may not feel as strongly as their colleague about an issue and wish to avoid a dissent. ${ }^{89}$ If the majority accommodates the third judge to some extent, the minority judge may be willing to compromise, given her own dissent aversion..$^{90}$ The majority may also aim for reciprocity - the "conscious or unconscious hope of reciprocal consideration in some future case in which [a judge] has a strong feeling and the other judges do not."91

Law does matter in the strategic model, but not because judges are predisposed to follow the law. Instead, law is relevant because of the strategic consequences of ignoring factors such as precedent, legal text, or legislative intent. Because strategic considerations are paramount, judges do not have as much discretion as the attitudinal model expects, although they retain their goal of maximizing achievement of their policy preferences.

\section{Craft Model}

The attitudinal model does not see law as a constraint on the behavior of judges, and the strategic model indicates that judges only care about what the law says for strategic reasons. A craft model, developed by Professors Sidney Shapiro (a coauthor of this piece) and Richard Levy, proposes that the primary motivation of judges is to follow the law, not to implement

85 The difference can also be attributed to deliberation between the minority and majority panel members. See infra notes 98-100 and accompanying text (discussing the impact of deliberation in split panels).

86 See supra Table 1, Row 3; see also supra note 24 (citing other studies noting the stronger ideological behavior of unified panels).

87 Pauline T. Kim, Deliberation and Strategy on the United States Courts of Appeals: An Empirical Exploration of Panel Effects, 157 U. PA. L. REv. 1319, 1344, 1346 (2009).

88 POSNER, supra note 54, at 31; Jonathan P. Kastellec, Hierarchical and Collegial Politics on the U.S. Courts of Appeals, 73 J. POL. 345, 346, 360 (2011) (finding that Republican outliers more strongly affect Democratic majorities than vice versa, as the Republicans can blow the whistle to a conservative Supreme Court).

89 POSNER, supra note 54, at 32; Kastellec, supra note 88, at 349.

90 See supra notes 62-63 and accompanying text (discussing dissent aversion).

91 POSNER, supra note 54, at 32. 
policy preferences. ${ }^{92}$ This model recognizes that judges are also interested in obtaining their policy preferences, but it proposes that judges will follow those preferences only to the extent that doing so does not reveal the judge as being outcome-driven, which in turn is a function of how determinate the law is. ${ }^{93}$

The previously discussed models assume that judges, like other policy players, want to maximize their policy preferences. Why suppose that judges, to the contrary, seek to adhere to legal doctrine? The craft model proposes that a judge's primary motivation is to follow the law, because a judge builds and enhances his or her reputation by preparing well-reasoned applications of legal rules to the circumstances of particular cases-a process described many years ago by Professor Karl Llewellyn as the judicial "craft." Craft behavior enhances a judge's reputation because it demonstrates competence in performing legal analysis and decisionmaking. ${ }^{95}$ This behavior also generates outcomes that are consistent and predictable, two results the legal profession values highly. ${ }^{96}$

The craft model, therefore, offers an alternative explanation for panel effects. As noted earlier, when appellate panels are split 2-1 along partisan lines, both Republican and Democratic judges vote less ideologically than they do when a panel is made up entirely of Republican or Democratic judges. ${ }^{97}$ While strategic reasons might give rise to this effect, the craft model points to deliberation among the judges as an explanation. ${ }^{98}$ The idea here is that the third judge persuades the other two judges by the exchange of information and the persuasiveness of reasoned argument. ${ }^{99}$ This is the view of Judge Edwards, for example: "During the course of judicial deliberations, judges more often than not persuade one another until a consensus is reached." 100

Despite the reputational advantages of craft behavior, this model recognizes that judges have and act on their policy preferences. In some instances, there is no conflict between a judge's ideology and engaging in craft behavior because the law in the case actually supports the judge's preferred outcome. At other times, the judge may feel so strongly about the

\footnotetext{
92 See Sidney A. Shapiro \& Richard E. Levy, Judicial Incentives and Indeterminacy in Substantive Review of Administrative Decisions, 44 DUKE L.J. 1051, 1056-57 (1995).

93 See id. at 1058.

94 See Karl N. Llewellyn, The Common law Tradition: Deciding Appeals 214 (1960).

95 Shapiro \& Levy, supra note 92 , at 1056

96 Id. There can also be a strategic element to craft behavior. Judges value a good reputation because it enhances their ability to influence other judges. $I d$. at 1055 . It is not necessarily easy to distinguish between strategic and craft motivations. See infra text following note 138 (discussing the difficulty of distinguishing the two models).

97 See supra note 24 and accompanying text.

98 POSNER, supra note 54, at 31.

99 Kastellec, supra note 88, at 349; Kim, supra note 87, at 1325.

100 Edwards \& Livermore, supra note 14, at 1964.
} 
outcome that she is prepared to risk the reputational loss that comes from abandoning craft behavior and ignoring, or at least eluding, the law. ${ }^{101}$ In general, however, this model sees craft behavior as dominant when the law is clear because this approach is the expected norm in the legal and judicial professions. ${ }^{102}$

Nevertheless, this model predicts that ideologically driven behavior will increase where the law is ambiguous and unclear. Judges will rely more heavily on ideology in such cases because they encounter less risk of reputational loss. Opinions that depart from clear doctrines expose judges to intensified scrutiny and accusations that an ideological-or outcomedriven-motivation has determined the result. Conversely, where legal rules or precedents in a case are indeterminate, a judge has more freedom to issue an outcome-oriented decision because the judge is less likely to be criticized for a failure to engage in craft behavior. ${ }^{103}$ It is difficult to argue that a judge has abandoned craft behavior where the applicable legal test permits him to obtain his policy preference without clearly exceeding the vague and ambiguous boundaries of that test.

Shapiro and Levy predicted considerable ideological behavior under the craft model in administrative law. ${ }^{104}$ The reason is that administrative law is chock-full of ambiguous and vague, even vacuous, legal doctrines that permit the judge to escape criticism for ideologically driven behavior. ${ }^{105}$ This result may even have a self-fulfilling quality. Because administrative law cases often have strong public-interest ramifications, judges may have resisted creating more determinate legal tests, which might hamstring their ability to make policy-based decisions. ${ }^{106}$

Still, this does not mean that judges will always be influenced by ideology when applying vague and ambiguous law. The degree of reliance depends on the extent of the ideological utility the judge gains in an outcome-oriented decision. ${ }^{107}$ In many cases, the ideological rewards may be small. As Judge Wald once noted, "For my part, I cannot even imagine having personal feelings about the appropriate regulatory standards for 'retrofitted cell-burners' as opposed to 'wall-fired electrical utility boilers,' to cite one recent and not atypical administrative law appeal." 108

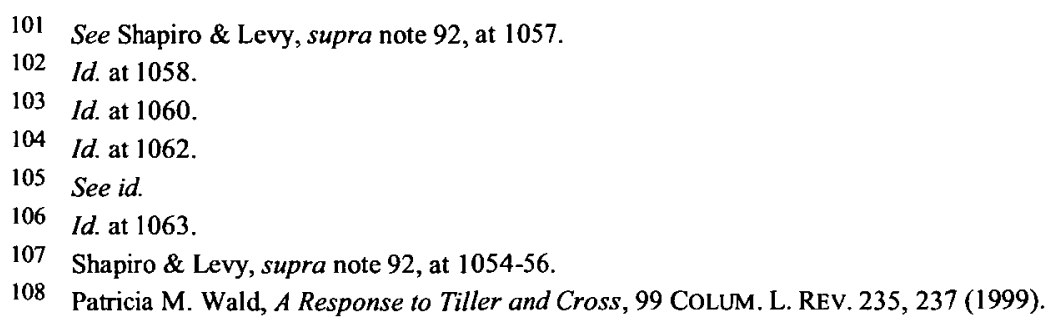




\section{Cognition Model}

The final model of judging likewise accepts the premise that first and foremost, judges intend to let the law be their guide. Like the craft model, this approach recognizes that the law can be ambiguous, and when it is, judges are influenced by their ideology in applying legal tests. In this model, however, the influence is a subconscious product of cultural cognition, rather than a conscious decision as it is in the craft model. ${ }^{109}$

A cognitive frame is a schema of interpretation that individuals use to understand and respond to events - a filter, if you will-that reflects the individual's political views, among other influences. Specifically, framing is a way of "selecting, organizing, interpreting, and making sense of a complex reality to provide guideposts for knowing, analyzing, persuading, and acting." 10 Through cognitive frames, individuals integrate "facts, values, theories, and interests." form their views about risks and benefits of putatively dangerous activities to their cultural evaluations of those activities."112 They do this because, as a matter of individual psychology, "it's much easier to believe that behavior one finds noble is also socially beneficial and behavior one finds base is dangerous rather than vice versa." "In a similar manner, the judges' views of what is required by the law are "shaped by their values-operating not as resources for theorizing law, but as subconscious, extralegal influences on their perception of legally consequential facts."114

Professors C.K. Rowland and Robert Carp considered the cognition model as an alternative to the attitudinal model in their study of the federal district courts. ${ }^{115}$ According to their results, between 1933 and 1988, "Democratic judges [were] 1.42 times more likely to render a liberal decision" than their Republican colleagues. ${ }^{116}$ In civil rights and civil liberties cases, Democrats voted for the plaintiff 1.73 times more often than Republicans did. ${ }^{117}$ And when considering a time period confined to more-recent years (1977-87), they found that Democratic judges were 3.19 times more likely to make a liberal decision in race discrimination cases than were their $\mathrm{Re}$ -

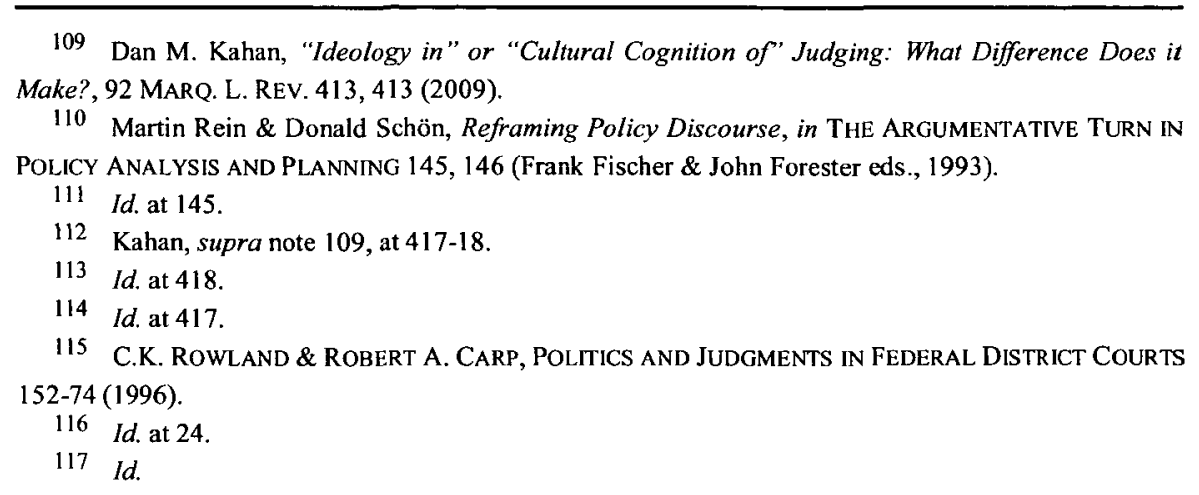


publican counterparts. ${ }^{118}$ Although Rowland and Carp agreed that their results were consistent with the attitudinal model, they criticized that model for failing to account for judges' underlying psychology. ${ }^{119}$

Using the psychological literature, they proposed their own model of judging - the cognitive model-which started with the proposition that "trial judges respect and adhere to the formal and informal norms contained in the judicial oath that binds them to fairness and objectivity." 120 Nevertheless, "judges are often given ambiguous legal cues ... and they are frequently confronted with conflicting pieces of evidence." ${ }^{21}$ Under conditions of uncertainty, judicial decisionmaking is a "two-stage process in which decisions are preceded by framing, that is, the mental transformation of ambiguous evidence and law into proximate decision cues." ${ }^{122}$ According to the cognitive model, the decisionmaking schemes that judges apply are related to ideology and to appointments:

\footnotetext{
When presidents ... establish ideological and policy-based criteria, they select and reinforce shared ideological and policy schemata. For example, when President Reagan pledged to appoint strict constructionists who opposed social regulation, this pledge implied a commitment to select highly schematic judges who shared relevant person, event, and role schemata and who would encode, retrieve, and interpret imperfect information by reference to those schemata. $^{123}$
}

In sum, the cognitive model attributes the differences in how Republicans and Democrats vote to the different ways in which they react to legal and factual uncertainty. Since Republican and Democratic judges will apply different cognitive frameworks to resolving uncertainties in the law and in the factual record, we should expect different voting records, particularly in ideologically salient areas such as civil rights.

Both the craft and cultural cognition models are consistent with the empirical evidence linking ideology and outcome in administrative law cases. They only differ as to the reason for the observed results. Regardless of whether values and ideology influence judges consciously (as in the craft model) or subconsciously (as the cognition model describes), the models agree that politics affects the outcomes of cases when the law is ambiguous and indeterminate.

\footnotetext{
118 Id. at 40 tbl.2-7.

119 Id. at 141.

120 Id. at 159.

121 RowLAND \& CARP, supra note 115, at 159.

122 Id. at 158.

123 Id. at 167 (citation omitted).
} 


\section{JUDICIAL CRAFT AND IDEOLOGY}

The four models of judicial behavior have differing accounts of the role of law; each offers a different and competing explanation for the empirical results. This Part explains why we reject the attitudinal model but find all of the other models plausible-indeed, the reality of judging likely involves all three to some degree. This Part then demonstrates why we see the craft model as being dominant, although this may be wishful thinking because we would like to think that judicial craft matters to judges.

\section{A. It's Not What the Judge Had for Breakfast}

The attitudinal model asserts that judges follow the law only when it suits their ideological preferences, an assertion that has the same effect on lawyers as chalk squeaking on a blackboard. Federal judges are free to follow their policy preferences because, having lifetime tenure, they can ignore the law or manipulate it to achieve outcome-oriented results with more or less no cost. Taken to its logical conclusion, the attitudinal model suggests that in cases that do not implicate a judge's ideological preferences, the outcome may depend on whether the judge's eggs were overcooked, a position taken by extreme legal realists to illustrate legal formalism's lack of bite. ${ }^{24}$

Empirical support for the attitudinal model, as noted earlier, came from disproving legal formalism. Having found an association between the political party of a judge and judicial outcomes, analysts claimed to have disproven that legal formalism explains how judges behave, leaving the attitudinal model as the default explanation. ${ }^{125}$

The amount of evidence for the attitudinal model makes it impossible to credit the claim that judges are mere umpires. Nevertheless, although this evidence discredits the formalist model, it does not prove that the attitudinal model is a more accurate description of how judges behave. ${ }^{126}$ Professor Tamanaha explains, "[f]rom the outset, the core mission of quantitative studies was to refute the (supposed) 'formalist' claim that judging is purely a matter of mechanical deduction. When framed this way, the crucial point of dispute is whether politics matters, not how much." 127

124 See Ronald DWORKIN, LAw's EMPiRE 36 (1986) ("Some realists.... said there is no such thing as law, or that law is only a matter of what the judge had for breakfast."). But see Frederick Schauer, The Limited Domain of the Law, 90 VA. L. REV. 1909, 1923 (2004) (contending this is not an accurate characterization of Legal Realism).

125 See supra note 70 and accompanying text.

126 See Tamanaha, supra note 49 , at 743

127 Id. (footnote omitted). 
A good deal of judicial behavior, as we have discussed, is difficult to reconcile with the attitudinal model. While ideology plays a role in judging, so does law. ${ }^{128}$ It is therefore necessary to consider the three models that account for the influence of law.

\section{B. The Habit of a Lifetime $e^{129}$}

The other three models see law as a constraining influence, but the strategic model sees it as secondary to ideology. Judges will follow the law, but only to fulfill an ideological strategy. We reject this ordering on the same basis as Shapiro and Levy did earlier. ${ }^{130}$ We see craft behavior as the default position because the legal and judicial professions expect it. Perhaps we are overestimating the influence of the professional norms on judges, but the rational-choice models that underlie political science ignore the considerable impact professionalization has on how professionals behave. ${ }^{131}$

We are not suggesting that judges do not act strategically. It makes sense to us that judges will consider others' reactions when contemplating an outcome in a case. Moreover, there is no way to know for sure whether a judge is respecting law because of craft or strategic behavior. Consider Whitman v. American Trucking Associations, Inc. ${ }^{132}$ In Whitman, the Court faced the issue of whether the EPA could take into account compliance costs when it established national ambient air quality standards ("NAAQSs") under the Clean Air Act. ${ }^{133}$ The statute's text clearly indicated costs were irrelevant, ${ }^{134}$ a conclusion backed up by a number of additional considerations, ${ }^{135}$ and all nine justices rejected a determined effort by the plaintiff and various amici to establish otherwise. ${ }^{136}$

128 See, e.g., infra notes 132-38 and accompanying text (recounting how law led Justice Scalia to an outcome he probably found ideologically uncongenial in a major environmental law case).

129 THE COOPER TEMPLE Clause, Habit of a Lifetime, on BLIND PILOTS (Morning Records 2003)

("And 'oh well' / You never could tell / You never could break / The habit of a lifetime.").

130 See Shapiro \& Levy, supra note 92, at 1057.

131 See Sidney A. Shapiro \& Ronald F. Wright, The Future of the Administrative Presidency: Turning Administrative Law Inside-Out, 65 U. MIAMI L. REV. 577, 588 (2011) (noting that analyses of bureaucracy have failed to take into account the role that professionalism plays in this context).

132531 U.S. 457 (2001).

133 Id. at 462.

134 See id. at 465 ("Were it not for the hundreds of pages of briefing respondents have submitted on the issue, one would have thought it fairly clear that this text does not permit the EPA to consider costs in setting the standards. The language, as one scholar has noted, 'is absolute."' (quoting DAVID P. CURRIE, AIR POllution: FEderal LaW AND ANALysis 4-15 (1981))).

135 See, e.g., id. at 490-92 (Breyer, J., concurring in part) (demonstrating that the legislative history indicated that the EPA was not to take costs into account).

136 Id. at 464-65 (majority opinion). Justice Breyer agreed with Justice Scalia's majority that the Clean Air Act barred the EPA from weighing implementation costs, but his rationale was based on policy concerns. Id. at 490 (Breyer, J., concurring in part). 
It would have been difficult for Justice Scalia, writing for the Court, to write a persuasive opinion reaching the opposite conclusion, given the little room for interpretation that Congress allowed to remain. ${ }^{137}$ Under the craft model, he would therefore have faced a considerable loss of face if he had concluded that Congress had required the EPA to take costs into account, or at least had not precluded the agency from doing so. But, as Judge Posner has pointed out, the outcome may have been the product of either strategic or craft behavior, or both:

\begin{abstract}
The statutory language provided no handle for recognizing a cost defense. ... Congress had left little interpretive leeway. [The contrary] opinion would have invited not only intense criticism but possible congressional retaliation, since environmentalism is politically popular and Congress does not like the courts to treat its statutes as first drafts that a judge is free to rewrite to promote his own personal policy agenda. ${ }^{138}$
\end{abstract}

This overlap presents a problem not easily solved. If judges adhere to law either for strategic reasons or for craft reasons, how do we know which motivation dominates? We nominate craft behavior, because it is the most consistent with the norms of the legal profession. The strategic model is slippery in this regard. It could include a judge's reputation as a strategic consideration on the ground that a judge's influence is a product, in part, of craft behavior. Viewed at this level, the strategic and craft models lose their separate identities. While we do not object to this move, it does aid the analysis to keep the two models separate.

\title{
C. Inside the Judicial Mind
}

Professor Kahan suggests that the cultural cognition model, "if true, spare[s] us from the disappointment associated with believing that judicial disagreement stems from self-conscious, and self-consciously concealed, political disregard for law." "139 Moreover, if true, the cognition model helps explain judges' continual insistence that except in a very few cases, they are not influenced by ideology. While such denials may not be true, at least they are not the product of posturing by judges to protect their privileged position. $^{140}$

Since framing, among other cognitive factors, affects everyone, we do not see how one can reject the cognitive model. Nevertheless, we find it difficult to believe that judges do not consciously think about the policy ramifications of the administrative law cases that they are deciding. Surely it dawns on them, for example, that a decision against the government

137 Id. at 491-92.

138 POSNER, supra note 54, at 52.

139 Kahan, supra note 109 , at 421.

140 Cf. supra note 75 and accompanying text (characterizing judges as "liars"). 
means less regulation, or vice versa. And, if the law permits that outcome, we would think it becomes more attractive to the judge who prefers less government rather than more, and vice versa. The judge might like to deny this reality, but that position would seem to be more a matter of self rationalization than subconscious behavior.

\section{Ideology and Administrative Law}

The strategic, craft, and cultural cognition models all recognize that judges will sometimes follow the law and will sometimes be guided by ideology, which brings us back to the question posed earlier: How significant is the influence of ideology? ${ }^{141}$ The answer to this question must vary across categories of cases; it is plain, however, administrative law is especially vulnerable. The craft model in particular suggests that ideology exercises greater influence in administrative law than in many other areas of law.

The craft model indicates that in order to escape criticism for ignoring the law, judges will engage in craft behavior as long as the law is fairly determinate. When law is vague and ambiguous, though, this risk recedes, and a judge enjoys greater freedom to follow her ideological inclinations. The likelihood that the judge will take this opportunity depends on the extent to which a given case triggers her ideological impulses.

Administrative law presents both conditions. Legal doctrines are vague and ambiguous, and given the subject matter-government regulationjudges are likely to have strong ideological interests in the outcomes of many cases. Still, as noted earlier, not every administrative law appeal has a high ideological salience. ${ }^{142}$ This may explain why outcome is strongly correlated with a judge's political party in controversial cases and less so in routine cases. ${ }^{143}$ Also, interest in outcome will vary from judge to judge, since some judges net greater ideological utility than others from outcomes that are consistent with their political (or other) preferences.

\section{THREE IMPROBABLE WAYS FORWARD}

Perhaps the most that can be said is that judging is a mix of law and ideology, a mix that cannot readily be denied, but also that cannot readily be quantified. This understanding does not deny a role to law, but it recognizes the inevitability of ideology in judging. Nor does ideology have a walk-on role. The weight of the evidence indicates that, even if it is not an

\footnotetext{
141 See supra Part I.B.

142 See supra note 108 and accompanying text.

143 See supra note 64 and accompanying text.
} 
equal partner, ideology is a supporting actor-at least in those areas of law dominated by indeterminacy, like much of administrative law.

This makes the threat of a judicial idcological lottery a serious concern. President Obama may be able to make the judicial lottery less likely to produce Republican-dominated panels, assuming he is reelected and Republicans are unable to stall votes on his nominees. Even so, adjusting the "tilt" in the judicial lottery would leave the outcome of particular cases dependent in uncomfortably large part on whether a litigant draws a panel with a Republican or Democratic majority.

What, if anything, can be done to lessen this problem? Here, we briefly explore three improbable possibilities that are suggested by the models of judicial behavior discussed above. The first, most obvious suggestion is also the easiest to reject: make administrative law clearer so courts have less discretionary wiggle room to apply it. Congress and the courts are, of course, extremely unlikely to change administrative law in this rather fundamental way - and they probably should not.

The second, most speculative option is to bring the politics out into the open. More specifically, judges could adopt a new craft norm of opinion writing that requires them to expressly state and to assess their own policy preferences in the course of reviewing administrative action. In addition to increasing transparency, such disclosures might help minimize the impact of judicial policy preferences on decisionmaking. We must admit, however, that such disclosures might tend to entrench and to legitimize judicial policy preferences rather than weaken them. Nor, we must also admit, are judges especially likely to embrace our proposed new craft norm.

Our third possibility is the most promising, in part because it does not seek major changes to the character of administrative law or to the norms of judging. It also enjoys the advantages of simplicity and ease of implementation in the unlikely event that Congress mandated it. As noted above, empirical studies demonstrate that ideological effects are much stronger for panels composed of judges from one party (D-D-D or R-R-R) than for mixed panels (D-D-R or R-R-D). ${ }^{144}$ This panel effect suggests that requiring mixed panels could significantly reduce politicization. Taking this step, however, would require legislation that explicitly acknowledges the political potential implicit in judging, an admission that would deeply offend our judicial traditions (and judges, too). As this direct approach is a nonstarter, we propose something slightly subtler that could have much the same effect: require five-judge panels for review of designated categories of administrative law appeals. 
A. The Most Impractical Possibility: Clearer Administrative Law

In the craft model, clear law leaves no room for judicial discretion and, thus, no chance for judicial ideological preferences to come into play. This almost tautological point suggests that Congress could solve the problem of politicization of judicial review of administrative action by enacting clearer statutes. ${ }^{145}$ Alternatively, Congress or the courts could develop clearer judicial-review doctrines that minimize judicial discretion. Neither task is easy, however, and neither is likely a good idea.

Indeterminacy exists in administrative law in part because Congress so often passes enabling acts that are extraordinarily broad and vague. The Federal Communications Commission has authority to regulate the airwaves "as public convenience, interest, or necessity requires." al Trade Commission is charged with rooting out "[u]nfair methods of competition in or affecting commerce." 147 The National Highway Traffic Safety Administration has responsibility to issue motor vehicle safety standards that are "practicable, meet the need for motor vehicle safety, and [are] stated in objective terms."

To implement such language, some enforcement entity-whether a court or an agency-must exercise discretion. Congress could, in theory, remove this discretion by writing more specific, detailed statutory instructions. It does not do so, however, because it lacks the information and/or the will to do so. In some instances, it may not cross anyone's mind during the legislative process that a particular issue will prove troublesome in the future. In others, the issue may be readily identifiable, but Congress may be unable to assemble a strong enough coalition to resolve it in a particularized away. In yet others, Congress may actively prefer to leave discretion with expert agencies to determine how to implement its vague instructions. ${ }^{149}$ Given these facts of legislative life, Congress will, as it has for hundreds of years, continue to enact vague agency organic acts that require vast discretion to implement. Moreover, to the degree we would prefer that (relatively) apolitical agencies and courts rather than Congress create governing law, this congressional habit is to the good.

\footnotetext{
145 Cf. Sunstein \& Miles, supra note 18, at 2225-26 (noting that "[p]erhaps the lesson of politicized voting is simple: Congress should legislate more clearly," but rapidly and persuasively dismissing this idea (emphasis omitted)).

14647 U.S.C. $\$ 303(2006)$.

147 15 U.S.C. $\$ 45(a)(1)(2006)$.

14849 U.S.C. $\$ 30111$ (a) (2006).

149 See Chevron U.S.A. Inc. v. Natural Res. Def. Council, Inc., 467 U.S. 837, 840, 865 (1984) (noting these possible explanations for Congress's failure to specify whether the phrase "stationary source" as used by the Clean Air Act Amendments of 1977 referred to individual pollution-emitting devices or entire plants of pollution-emitting devices, or could refer to either category (internal quotation marks omitted)).
} 
Judicial review doctrines purport to allocate the discretion created by (vague) substantive law between agencies and courts. Of particular note, the Chevron doctrine allocates to agencies the power to choose among reasonable statutory constructions. ${ }^{150}$ The Skidmore doctrine, by contrast, instructs courts to impose the statutory constructions they deem best after giving due regard to any relevant agency efforts. ${ }^{151}$ On the face of the matter, then, Chevron shifts discretion toward agencies; Skidmore shifts discretion toward courts.

Courts determine which of these two standards to apply based on "Chevron Step Zero," 152 which is largely the product of two Supreme Court cases, United States v. Mead Corp. ${ }^{153}$ and Barnhart v. Walton. ${ }^{154}$ In essence, Mead instructs courts to apply Chevron deference to agency statutory constructions produced via extensive, relatively transparent procedures (e.g., notice-and-comment rulemaking or formal adjudication). ${ }^{155}$ Under Barnhart, the applicability of Chevron to other agency statutory constructions depends on a multi-factor, totality-of-the-relevant-circumstances inquiry. ${ }^{156}$ This framework leaves courts with considerable discretion with regard to whether to apply Chevron or Skidmore to agency statutory constructions produced without extensive procedure. Requiring courts to apply Chevron deference across the board ${ }^{157}$ would strip courts of their discretion to allocate interpretive authority to themselves rather than to agencies and perhaps reduce courts' power to impose their own policy and political preferences in the name of statutory construction.

150 See id. at 843-44 (instructing courts to affirm an agency's construction of a statute it administers so long as this construction is permissible (i.e., reasonable) and does not contravene clearly expressed congressional intent).

151 Skidmore v. Swift \& Co., 323 U.S. 134, 140 (1944) (observing that agency interpretations lacking the force of law provide "guidance" to courts and litigants). In Skidmore, the Court considered whether a group of Texas firefighters had earned overtime pay for the time they spent on call sleeping within earshot of their employer's factory but were not physically on the premises. Id. at 135-36. The Department of Labor had interpreted the Fair Labor Standards Act as authorizing the Administrator to construct guidelines for determining on a case-by-case basis whether a particular type of off-site work required reimbursement. $I d$. at 137-38. A unanimous Court held that the district court had erred in disregarding the Administrator's guidelines, but Justice Jackson explicitly reserved some discretion about agency action for the courts. Id. at 140 .

152 See generally Cass R. Sunstein, Chevron Step Zero, 92 VA. L. REV. 187 (2006).

153533 U.S. 218 (2001).

154535 U.S. 212 (2002).

155 See Mead, 533 U.S. at 230 ("Thus, the overwhelming number of our cases applying Chevron deference have reviewed the fruits of notice-and-comment rulemaking or formal adjudication.").

156 Barnhart, 535 U.S. at 222 (noting that Chevron's applicability turns on consideration of an indeterminate set of factors including agency expertise, consistency of the agency's interpretation over time, statutory complexity, and so on).

157 Justice Scalia would have preferred this simple rule. See Mead, 533 U.S. at 241 (Scalia, J., dissenting). 
One might object that abandoning Chevron Step Zero would carry the unacceptable price of forcing courts to defer to agency statutory constructions that do not deserve strong deference because they are not the products of a transparent process designed to promote application of agency expertise. ${ }^{158}$ There is, however, a deeper objection that is more to the present point: A court's nominal choice of deference doctrine may not affect outcomes very much. Summarizing the results of recent empirical work, Professor Richard Pierce recently observed:

With one notable exception, the studies suggest that a court's choice of which doctrine to apply in reviewing an agency action is not an important determinant of outcomes in the Supreme Court or the circuit courts. The ranges of affirmance rates by doctrine are as follows: Chevron, $60 \%$ to $81.3 \%$; Skidmore, $55.1 \%$ to $73.5 \%$; State Farm, $64 \%$; substantial evidence, $64 \%$ to $71.2 \%$; de novo, $66 \%$. All of the ranges of findings overlap, and doctrinally-based differences in outcome are barely detectable. ${ }^{159}$

By contrast, factors that do appear to affect outcomes to some degree include whether the agency construction at issue is longstanding, comparative institutional expertise and ideology. ${ }^{160}$

The courts' apparent failure to give real, operative meaning to their current morass of deference doctrines suggests that clearer, more potent doctrines might be in order. Along these lines, some have suggested the possibility of replacing the Chevron doctrine with a "super-Chevron" doctrine and "hard-look" review for arbitrariness with "soft-look" review. ${ }^{161}$ The very fact that deference doctrines affect judicial outcomes less than one might expect, however, suggests that stiffening these doctrines would produce no practical effects. Also, it bears noting that most judicial review doctrines already ostensibly require courts to review agency action for mere

158 See id. (majority opinion) (contending that courts should "tailor deference to [fit the] variety" of "multifarious agency action[s]").

159 Richard J. Pierce, Jr., What Do the Studies of Judicial Review of Agency Actions Mean?, 63 ADMIN. L. REV. 77, 85 (2011); see also Sunstein \& Miles, supra note 18, at 2222 ("No clear evidence shows whether courts that use Skidmore, rather than Chevron, end up with more invalidations, greater politicization, or both.").

160 Pierce, supra note 159 , at 86-90.

161 See, e.g., Richard J. Pierce, Jr., Judicial Review of Agency Actions in a Period of Diminishing Agency Resources, 49 ADMIN. L. REV. 61, 90-91 (1997) (contending that courts should adopt "a less demanding version of the duty to engage in reasoned decisionmaking in response to the phenomenon of diminishing agency resources"); Sidney A. Shapiro, Substantive Reform, Judicial Review, and Agency Resources: OSHA as a Case Study, 49 ADMIN. L. REV. 645, 652-54 (1997) (expressing sympathy for a "soft-look" approach to judicial review for reasoned decisionmaking, but also expressing a preference for "pass-fail" review (internal quotation marks omitted)). But see Sunstein \& Miles, supra note 18, at 2222-24 (concluding that some "softening of [judicial] review" is likely in order, but also noting that this move could undermine the beneficial disciplining effect that judicial review has on agency action and increase the problem of "politicized validations" of agency action (emphasis added)). 
reasonability. ${ }^{162}$ In one sense, calling for still-stronger deference doctrines would be tantamount to demanding that courts defer to agency actions they consider unreasonable.

On a related note, the experience of Professors Shapiro and Richard Levy provides a cautionary tale on how difficult it can be to devise new standards of review that further limit judicial discretion. At a symposium of administrative law professors, they proposed legislative language that Congress could adopt to make the Administrative Procedure Act's judicialreview provisions less vague and ambiguous. ${ }^{163}$ Their strategy was to replace open-ended, scope-of-review standards with specific inquiries that eschewed, as far as possible, the use of vague adjectives reflecting degrees of deference. To cut down on opportunities for (discretionary) manipulation of categories of review, they sought to develop a single, comprehensive set of inquiries that applied to all agency decisions.

Not to put too fine a point on it, the distinguished scholars who commented on the Shapiro-Levy proposal were quite dubious of its merits. Besides doubting that Congress would ever pass an amendment resembling the proposal, Professor Ron Levin found that it was "at least open to ques-

162 See, e.g., Chevron U.S.A. Inc. v. Natural Res. Def. Council, Inc., 467 U.S. 837, 843 (1984) (instructing courts to defer to "permissible" administrative statutory constructions); Motor Vehicle Mfg. Ass'n v. State Farm Mut. Auto. Ins. Co., 463 U.S. 29, 43 (1983) (explaining that arbitrariness review of agency policy decisions checks for a "rational connection between the facts found and the choice made" (quoting Burlington Truck Lines, Inc. v. United States, 371 U.S. 156, 168 (1962)) (internal quotation marks omitted)); Universal Camera Corp. v. NLRB, 340 U.S. 474, 477 (1951) (characterizing "substantial evidence" as "such relevant evidence as a reasonable mind might accept as adequate to support a conclusion" (quoting Consolidated Edison Co. v. NLRB, 305 U.S. 197, 229 (1938)) (internal quotation marks omitted)); Ass'n of Data Processing Serv. Orgs., Inc. v. Bd. of Governors of Fed. Reserve Sys., 745 F.2d 677, 683 (D.C. Cir. 1984) (Scalia, J.) (contending persuasively that arbitrariness review of facts applies the same force-of-rationality review as the "substantial evidence" test).

163 Specifically, they proposed that Congress amend the APA's judicial review provision, 5 U.S.C. $\S 706$, to provide:

\section{$\S 706$. Scope of Review}

The reviewing court shall ... (2) hold unlawful and set aside agency actions, findings, and conclusions if the court determines that

(A) the agency decision violates a constitutional right, power, privilege, or immunity;

(B) the agency decision was made without observance of procedure required by law;

(C) the agency decision violates its statutory mandate or other statutory provisions because:

(1) the issue has been specifically resolved by explicit statutory language;

(2) the issue has been specifically resolved by legislative history manifesting an unmistakable congressional intent; or

(3) a contrary interpretation of the statute is unequivocally required by the traditional tools of statutory construction;

(D) the agency has not offered a valid policy explanation for its decision because:

(1) it relied on policy concerns that were precluded by statute; or

(2) entirely failed to consider an important aspect of the problem; or

(E) the agency has not offered a logically coherent explanation in terms of agency expertise, credibility determinations, or policy considerations, of

(1) why the evidence in the record supports its decision; or

(2) why the contrary evidence does not preclude the decision.

Shapiro \& Levy, supra note 92, at 1074. 
tion ... whether Shapiro and Levy have succeeded in offering language that would actually clarify the law." ${ }^{164}$ Professor Tom McGarity forecasted that the proposed solution had "little chance of success in the real world" for a number of reasons, including "it is very hard to draw clear lines and craft clean categories when one is bound by the limitations of the English language." 165 Along similar lines, Professor Pierce's criticisms focused on the "the extreme difficulty of writing detailed instructions to reviewing courts that offer a realistic prospect of enhanced determinacy with respect to the doctrines applicable to judicial review of agency actions."166

Notwithstanding the Shapiro-Levy proposal's failure to gain traction, just suppose that one could devise a stronger deference regime and persuade Congress to impose it on the courts (or the courts to impose it on themselves). The price of such a move might be too great. The most obvious outcome of genuinely stronger deference would be an expanded scope for arbitrary action by agencies. If, for instance, courts take "soft looks" rather than "hard looks" at agency policy choices, they will lessen the administrative cost of judicial review and lessen the likelihood of incorrectly determining that agency action was arbitrary. They will also increase the likelihood of failing to vacate agency action that is irrational.

In addition, reducing judicial scrutiny of agency action may cause agencies to invest less in careful decisionmaking. If agencies are, as a rule, "trying too hard" to justify their actions, then such a reduction could prove beneficial. ${ }^{167}$ Removing the threat of intrusive judicial review might, however, encourage agencies to cut too many corners in their decisionmaking, thus causing social losses. ${ }^{168}$

The benefits of increasing deference as a means of reducing politicization of judicial review are, in any event, open to question. As Sunstein and Miles recently observed, strengthening deference could have the perverse effect of increasing politicization insofar as it would give judges greater freedom to indulge their political inclinations to validate agency actions. ${ }^{169}$ Put another way, strengthened deference might cause Republicandominated panels to be quicker to affirm conservative decisions and Democrat-dominated panels to be quicker to affirm liberal decisions.

\footnotetext{
164 Ronald M. Levin, Judicial Review and the Uncertain Appeal of Certainty on Appeal, 44 DUKE L.J. 1081, 1096 (1995).

165 Thomas O. McGarity, On Making Judges Do the Right Thing, 44 DUKE L.J. 1104, 1104, 1106 (1995).

166 Richard J. Pierce, Legislative Reform of Judicial Review of Agency Actions, 44 DUKE L.J. 1110 , 1132 (1995).

167 Cf. Thomas O. McGarity, Some Thoughts on "Deossifying" the Rulemaking Process, 41 DUKE L.J. 1385, 1387-88 (1992) (observing that the rulemaking process has evolved into a vastly more burdensome process for agencies and that "[i]mportant rulemaking initiatives grind along at such a deliberate pace that they are often consigned to regulatory purgatory, never to be resurrected again").

168 Sunstein \& Miles, supra note 18 , at 2223.

169

Id. at 2224 .
} 
Lastly, it bears noting that, were a reformation of judicial-review doctrine to succeed in imposing a stronger, more determinate regime, it would implicate the age-old problem of whether it is better to use "standards" or "rules" to make decisions. ${ }^{170}$ The adoption of a more determinate doctrine (i.e., a rule-like doctrine) should lead to less judicial discretion, but it would also deny judges the power to craft their decisions to fit the situation in hand. ${ }^{171}$

In sum, we should not expect-and probably should not wish forCongress to take discretion out of the system by enacting clearer substantive statutes. Vague substantive statutes grant discretion to those who enforce them. Neither Congress nor the courts are likely to attempt to reform judicial review doctrines to allocate this discretion more clearly and fully to agencies rather than courts. Any effort in this direction would, in any event, likely be frustrated by scope-of-review doctrinal formulations' limited power to govern actual judicial decisionmaking. Moreover, even if a stronger deference doctrine could be devised, agreed upon, and successfully implemented, it might carry too great a cost.

\section{B. The Most Speculative Possibility: Judicial Policy Preference Disclosures}

On one level, the empirical studies discussed above merely confirm something that we know about judges because we know that they are human beings: each judge's personal mix of values, political commitments, policy preferences, and ideology affects how she sees the world. As a result, judges naturally vary with regard to whether they deem a given controversial agency action to be a good, bad, or indifferent thing. When an agency action affects a matter that is near and dear to a reviewing judge's heart, the judge's reaction may be strong and clear; where an agency action affects a matter that the judge cares or knows little about, the judge's reaction may be weak and tentative. Still, over the run of cases, we know that judges' values strongly affect judicial review of agency action in ideologically charged cases where indeterminate law leaves room for judicial discretion.

Current law nonetheless encourages courts to sweep this influence under the rug, urging that judges' preferences are immaterial to whether they will uphold an agency action. ${ }^{172}$ Perhaps, however, judges should take the

170 See generally Louis Kaplow, Rules Versus Standards: An Economic Analysis, 42 DUKE L.J. 557 (1992).

171 Cf. United States v. Mead Corp., 533 U.S. 218, 234-35 (2001) (contending that courts need flexibility to modulate deference, given the many forms of agency action).

172 See, e.g., Massachusetts v. EPA, 549 U.S. 497, 560 (2007) (Scalia, J., dissenting) ("No matter how important the underlying policy issues at stake, this Court has no business substituting its own 
very opposite approach and reveal their preferences by candidly disclosing whether and why they believe an agency action is, by their lights, a good or bad thing. Such disclosures would at minimum enhance transparency and honesty. Also, on an admittedly speculative note, there are grounds for hoping that such a disclosure regime would lessen the force of judicial preferences on administrative law outcomes.

Although discretion in administrative law is pervasive, it is far from absolute. Where the law leaves discretionary space for a decisionmaker to choose between options $A, B$, and $C$, the decisionmaker may not legally decide by throwing a dart or favoring the better-looking litigant. In the context of judicial review of discretionary agency action, the courts instead insist that agencies base their decisions on reasoned decisionmaking, which requires an agency to consider the "relevant factors," avoid consideration of irrelevant factors and avoid any "clear error in judgment." 173 For instance, the Clean Air Act instructs the EPA to promulgate NAAQSs that limit emission of pollutants to protect the "public health" with "an adequate margin of safety." 174 The statute forbids the agency from considering costs in the course of establishing pollutant levels. ${ }^{175}$ It follows that EPA's public justification for a NAAQS should demonstrate that the agency considered the relevant factors of public health and safety and, on pain of vacation, should avoid discussion of the irrelevant factor of economic effects. ${ }^{176}$

Of course, on a moment's reflection, it should be obvious that these same basic demands of reasoned decisionmaking should and do apply to judges' discretionary decisions as well. Whether acting as an administrator or a judge, a person with discretion to determine policy should (a) choose the best policy she deems available from those legally permissible, and (b) explain why she thought it was the best choice based upon considerations the law deems allowable. In keeping with this observation, in many judicial opinions, judges make quite plain the intertwined policy and politi-

desired outcome for the reasoned judgment of the responsible agency."); id. at 535 (Roberts, C.J., dissenting) (admitting that "[g]lobal warming may be a 'crisis"" but that it presents a problem for the policymakers of the political branches to address (quoting Petition for Writ of Certiorari at 26, Massachusetts, 549 U.S. 497 (No. 05-1120))); Chevron U.S.A. Inc. v. Natural Res. Def. Council, Inc., 467 U.S. 837,865 (1984) ("Courts must, in some cases, reconcile competing political interests, but not on the basis of the judges' personal policy preferences. In contrast, an agency to which Congress has delegated policymaking responsibilities may, within the limits of that delegation, properly rely upon the incumbent administration's views of wise policy to inform its judgments.").

173 See, e.g., Motor Vehicle Mfg. Ass'n v. State Farm Mut. Auto. Ins. Co., 463 U.S. 29, $42-44$ (1983) (quoting Bowman Transp., Inc. v. Ark.-Best Freight Sys., Inc., 419 U.S. 281, 285 (1974), and Citizens to Preserve Overton Park, Inc. v. Volpe, 401 U.S. 402, 416 (1971)) (internal quotation marks omitted) (stating the canonical doctrine governing review for reasoned decisionmaking).

174 See 42 U.S.C. $\$ 7409$ (b)(1) (2006).

175 Whitman v. Am. Trucking Ass'n, 531 U.S. 457, 465 (2001) (holding that EPA lacks statutory authority to consider costs in determining NAAQSs).

176 Id. at 471 n. 4 (noting that were EPA to consider costs of attainment in developing a NAAQS, the resulting standard should be vacated as illegal). 
cal preferences that help drive their constructions of vague statutory or constitutional law. Justice Stevens' dissent in Citizens United v. Federal Election Commission ${ }^{177}$ demonstrates that he thinks it a dreadful idea to permit corporations to influence elections by allowing them to make unlimited donations. ${ }^{178}$ Justice Thomas thinks that much of the Court's handiwork in the war on terror borders on the criminally stupid. ${ }^{179}$ Such expressions are in keeping with the long-accepted, realistic view that judges frequently should engage in policy analysis and assessment to reach their decisions.

Modern administrative law, however, generally purports that agencies, not courts, should control the policymaking discretion necessary to implement an agency's statutory mission. ${ }^{180}$ On this view, judges' policy views become "irrelevant factors" that ought not taint their review of agency action. One might therefore expect judges - as indeed they typically do- to avoid expressly discussing their personal policy views in opinions reviewing agency action. Still, the empirical studies discussed above, ${ }^{181}$ along with a basic appreciation of human psychology, demonstrate that judges' policy preferences (and their intertwined political preferences and values) do affect outcomes. This conclusion suggests that judges should discuss their personal assessments of agency action not because they are supposed to matter, but because they have to matter. Put another way, judges should discuss their policy preferences when reviewing agency action not because their preferences amount to relevant factors, but because they are, to coin a phrase, "inevitable factors."

There are certainly reasons to preserve the status quo of sweeping the influence of judicial preferences under the rug. For one thing, there is much to be said for keeping up appearances. Acceptance of judicial power depends, in part, on the perception that judges can administer law in a relatively neutral, rather than politicized, matter. More extensive, more syste-

177130 S. Ct. 876 (2010).

178 See id. at 930 (Stevens, J., dissenting) ("Our lawmakers have a compelling constitutional basis, if not also a democratic duty, to take measures designed to guard against the potentially deleterious effects of corporate spending in local and national races.").

179 See Hamdi v. Rumsfeld, 542 U.S. 507, 595 (2004) (Thomas, J., dissenting) (contending that the procedural framework adopted by the plurality for reviewing executive detention of persons as "enemy combatants" in the war on terror "will destroy the intelligence gathering function," waste military officials' time with litigation, and "probably require the Government to divulge highly classified information to the purported enemy combatant, who might then upon release return to the fight armed with our most closely held secrets").

180 As the Court stated near the end of Chevron:

Courts must, in some cases, reconcile competing political interests, but not on the basis of the judges' personal policy preferences. In contrast, an agency to which Congress has delegated policymaking responsibilities may, within the limits of that delegation, properly rely upon the incumbent administration's views of wise policy to inform its judgments. While agencies are not directly accountable to the people, the Chief Executive is, and it is entirely appropriate for this political branch of the Government to make such policy choices ... .

Chevron U.S.A. Inc. v. Natural Res. Def. Council, Inc., 467 U.S. 837, 865 (1984).

181 See supra Part I.A. 
matic disclosure of judges' intertwined policy and political preferences might undermine this perception, thus weakening the courts and encouraging the cynical, untrue view that judging is nothing but politics garbed in robes.

Also, there is something to be said for shame. It is possible that treating the force of judicial policy preferences on outcomes as a dirty little secret helps minimize their effects. It may be a short step from adopting a judicial norm of freely admitting policy preferences to accepting that it is legitimate to try to further them, rather than to resist them.

There are, however, several reasons to favor a new norm that judges forthrightly disclose their own policy preferences when reviewing agency action. The first rationale, which largely speaks for itself, is that the values of transparency and candor suggest that judges should discuss those factors that $d o$ in fact affect their decisions. Second, if judicial disclosures of policy preferences are at all self-critical, they may help judges curb the force of their own biases. Third, the craft model of judging suggests that such disclosures would raise the cost of issuing opinions that confirm a judge's preferences and reward judges for authoring opinions that conflict with them.

Consider in these regards the blockbuster global-warming case of a few years ago, Massachusetts $v . E P A,{ }^{182}$ in which the justices reviewed the EPA's denial of a petition in which the state of Massachusetts asked the EPA to initiate rulemaking under the Clean Air Act to control greenhousegas emissions from new motor vehicles. ${ }^{183}$ The five-justice majority ruled that (1) Massachusetts had standing to contest EPA's denial; (2) the EPA had statutory authority under the Act to regulate greenhouse-gas emissions as "air pollutants"; and (3) the EPA's refusal to decide whether greenhouse gas emissions endangered public health and safety was arbitrary. ${ }^{184}$ Four justices joined the two dissenting opinions. Chief Justice Roberts devoted his dissent to blasting the majority's standing analysis; ${ }^{185}$ Justice Scalia directed his dissent at the merits issues. ${ }^{186}$

All three of the questions presented in Massachusetts $v . E P A$ implicated judicial discretion under any realistic understanding of that phrase. Indeed, if we indulge the premise that all nine justices are reasonable people, the five-to-four split as to each issue demonstrates that there was room for reasonable minds to disagree. The preferences, values, and worldviews that the justices brought to the table had to affect their conclusions under such circumstances. In none of the opinions, however, did the justices expressly discuss their personal policy reactions to the EPA's denial of the state's petition. The majority opinion came considerably closer

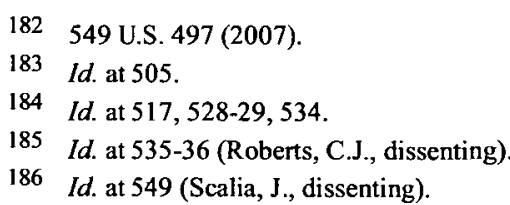


than the dissents in this regard as it cited the record at several points for the proposition that global warming was real and a major problem-points that the EPA had not contested. ${ }^{187}$ Chief Justice Roberts and Justice Scal ia were far cagier, insisting that it simply was not the judiciary's job to determine whether global warming was, as petitioners would have it, "the most pressing environmental problem of our time."188

The dissent's refusal to take sides accords well with the current norms of judicial opinion writing. Suppose, however, that the justices had instead explained their personal views with regard to whether the EPA's denial of the rulemaking petition was a great or terrible thing for the world or something in between. Justice Stevens, it turns out, is inclined to think that the EPA's denial of the petition was an epic and catastrophic policy mistake given a broad consensus of scientists that global climate change poses a substantial risk of cataclysm. ${ }^{189}$ Chief Justice Roberts thinks there may be something to this issue underneath all the hype but that we'll figure out how to deal with it without a massive regulatory power grab. ${ }^{190}$ And so on.

The point of such an exercise, it should be stressed, would not be to force judges to write thousand-volume treatises determining once and for all the policy merits of administrative actions. The point, rather, would be for judges to reveal their preferences-which might take the form of firm conclusions in some cases or mere suspicions and surmisals in others.

In addition to doing a better job of telling the truth, judicial opinions containing such disclosures would permit their readers to better assess their quality and persuasiveness. One might fondly hope that this type of disclosure would also cause judges to become more sensitive to the strength of their potential biases, thus weakening them. This sort of effect may be especially likely were judges to take the time to explore why others might not share their policy views-i.e., to "consider the opposite."191

187 See, e.g., id. at 521-22 (majority opinion) (observing that "[t]he harms associated with climate change are serious and well recognized" and noting that petitioners allege that a "strong consensus" among qualified scientific experts holds that global warming threatens rising sea levels, severe damage to natural ecosystems, stronger storms, decreased snowpack in mountainous regions, and related harms (second internal quotation marks omitted)).

188 Massachusetts, 549 U.S. at 535 (Roberts, C.J., dissenting) (quoting Petition for Writ of Certiorari at 22, Massachusetts, 549 U.S. 497 (No. 05-1120)) ("Global warming may be a 'crisis,' .... [but it] is not a problem ... that has escaped the attention of policymakers in the Executive and Legislative branches of our Government ...." (quoting Petition for Writ of Certiorari at 26, Massachusetts, 549 U.S. 497 (No. 05-1120))); see also id. at 560 (Scalia, J., dissenting) ("The Court's alarm over global warming may or may not be justified, but it ought not distort the outcome of this litigation.").

189 See id. at 521-22 (majority opinion).

190 See id. at 535 (Roberts, C.J., dissenting).

191 Paul M. Secunda, Cultural Cognition at Work, 38 FLA. ST. U. L. REV. 107, 14344 (2010) (quoting Nancy Levit, Confronting Conventional Thinking: The Heuristics Problem in Feminist Legal Theory, 28 CARDOZo L. REv. 391, 436-37 (2006)) (internal quotation marks omitted) (noting that the debiasing technique of considering the opposite has proven effective in various contexts and suggesting that this technique might work for judges as well); see also Stephanos Bibas, Plea Bargaining Outside 
Suppose for the sake of argument, however, that judicial policy preference disclosures would do nothing to affect the strength of a given judge's preferences and biases. Even so, such disclosures might reduce ideological effects on judicial review of agency action for two reasons, both of which broadly relate to craft norms.

First, one major function of a judicial opinion is to provide a reasonable, persuasive justification for a judge's decision. Judges work hard at this task, in part to achieve and to retain a reputation among lawyers and fellow judges as being skilled and honorable. A judge who admits to a preference for a certain outcome has put herself into a rhetorical hole insofar as we expect judges (and people in general) to rationalize justifications for outcomes they want to reach anyway. Generally speaking, writing a persuasive opinion justifying an outcome you have already admitted to favoring should be harder than justifying an outcome towards which you are personally neutral or opposed.

Second, judges wish to be regarded not as mere robed politicians, but as, well, judges. This fact helps explain strong resistance from some on the bench to the notion that empirical studies demonstrate politicization of the judiciary. It also suggests that, although judges no doubt derive utility from issuing opinions that favor their preferences, they could also derive utility from issuing opinions that publicly defy their political preferences because these opinions demonstrate their strong judicial character. ${ }^{192}$ By raising the profile of judicial political preferences, a norm of disclosure could strengthen the signal of quality that a judge sends by defying her own preferences.

Much of this Article's analysis has been, in all frankness, speculative. It is not possible to predict with anything like certainty what effects would flow from a norm requiring judicial opinions to focus on expressly identifying a judge's policy preferences regarding agency actions. The current norm, however, requires us to ignore something we all know to be true-or at least to insist that it does not matter much. Even though judges are supposed to respect agencies' policymaking expertise and authority, judges'

the Shadow of Trial, 117 HARV. L. REV. 2463, 2523-24 (2004) (collecting studies to support the proposition that "[p]sychologists have repeatedly found that considering the opposite reduces overconfidence, biased information assimilation, biased hypothesis testing, and excessive perseverance of beliefs"); Gregory Mitchell, Libertarian Paternalism Is an Oxymoron, 99 Nw. U. L. REV. 1245, 1256 (2005) (collecting studies for the proposition that "counseling decisionmakers to consider counterarguments and opposing viewpoints is one of the most successful debiasing measures").

192 Commenting in this vein, Judge Posner has observed:

The pleasure of judging is bound up with compliance with certain self-limiting rules that define the "game" of judging. It is a source of satisfaction to a judge to vote for the litigant who irritates him, the lawyer who fails to exhibit proper deference to him, the side that represents a different social class from his own; for it is by doing such things that you know that you are playing the judge role, not some other role, and judges for the most part are people who want to be-judges.

Richard A. Posner, What Do Judges and Justices Maximize? (The Same Thing Everybody Else Does), 3 SUP. CT. ECON. REV. 1, 28 (1993). 
intertwined policy, political, and ideological preferences all affect outcomes on judicial review of agency action. It may be that hiding or trying to minimize this influence both enhances the appearance of judicial legitimacy and curbs politicization of the courts by keeping the force of judicial preferences a dirty little secret.

Still, we submit that there is an alternative worth considering. Let judges be the first to admit that their personal assessments of the merits of an agency's action affect review. Let judges disclose these preferences, to the degree they exist, and try to examine them self-critically. Insofar as admitting the existence of a problem is more forthright than hiding it, such disclosures could enhance the legitimacy of judicial review of agency action rather than lessen it. Moreover, by bringing potential bias out into the open, a norm of disclosure might decrease the force of judicial policy preferences by encouraging judges to "debias" themselves, increasing the cost of pushing judicial policy preferences, and rewarding judges who defy their own policy preferences.

\section{The Neatest Solution: Expand Panel Size}

It might be fair to say that our most impractical and speculative proposals try to unravel the Gordian knot of politicization of judicial review of agency action by seeking major changes to the character either of judicialcraft norms or of administrative law itself. Given the unlikelihood of such developments, we regard these proposals as provocative thought experiments (although we would certainly like to see courts try out our proposed disclosure regime). Our last proposal, the most practical one, tries to slice the knot with an institutional tweak: bigger panels for important cases.

Recall that one of the stronger findings of recent empirical research is that panels composed solely of Democrats (D-D-D) or Republicans (R-RR) show far stronger ideological effects than mixed panels (D-D-R or D-RR). ${ }^{193}$ Indeed, Sunstein and Miles concluded in a study of Chevron voting patterns in the Courts of Appeals that, on mixed panels, Democratic and Republican appointees vote in much the same way as each otherregardless of which party holds the panel's majority. ${ }^{194}$ This finding suggests that the quick and easy way to lessen politicization of administrative

193 See supra note 24 (citing studies).

194 Sunstein \& Miles, supra note 18, at 2203 (noting, but with caution due to small sample size, that "[o]n mixed panels, politicized voting is greatly reduced; the behavior of Democratic appointees, on such panels, is very close to that of Republican appointees" (emphasis omitted)); see also Sunstein \& Miles, Do Judges Make Regulatory Policy?, supra note 24, at 863-65 (identifying and discussing panel effects). 
law would be to require mixed panels for review of significant administrative actions. ${ }^{195}$

After identifying this possibility in a recent article, Sunstein and Miles made short and persuasive work of killing it. ${ }^{196}$ The most compelling objection is that requiring mixed panels - whether by statute or judicial rulewould violate a long, proud, deeply ingrained tradition of doublethink and denial. Imposing mixed panels would loudly concede that judging, particularly in the context of administrative law, contains a strong political element. This concession might seem unobjectionable insofar as it turns out to be, in a word, true. We should expect judges to resist this concession fiercely, however, given that accepting it would require them to admit that they cannot control their political impulses without severe external restraint. ${ }^{197}$ Moreover, proclaiming the political element of judging so loudly and concretely might tend to undermine the ethic that even if judges cannot eliminate this aspect of decisionmaking, they should at least use their best efforts to minimize it. In other words, admitting the political element may tend to strengthen and to legitimize it. ${ }^{198}$ Thus, for a mix of practical and symbolic reasons, requiring three-judge panels to be mixed is a nonstarter.

There is, however, an alternative that might achieve much the same effects, one that has lower potential to cause collateral damage and to spark political objections: require randomized five-judge panels for review of especially significant agency action. ${ }^{199}$ Legislative rules promulgated through notice and comment (especially those with significant economic impact) might be logical candidates for such treatment.

The straightforward basis for this proposal is that the likelihood that a random selection of judges from a politically mixed pool will produce an unmixed panel of five is far smaller than the likelihood of producing an unmixed panel of three. The size of this reduction depends on the mix of the pool, which varies dramatically across circuits from a twoDemocrat/nine-Republican split on the Eighth Circuit among active judges

195 See, e.g., Emerson H. Tiller \& Frank B. Cross, Colloquy, A Modest Proposal for Improving American Justice, 99 COLUM. L. REV. 215, 233 (1999) (proposing a mechanism for producing mixed panels).

196 Sunstein \& Miles, supra note 18 , at 2227-28.

197 Wald, supra note 108, at 254-55 (contending that requiring mixed panels would "change[] radically the public's and the judge's own perception of her role"); $c f$. Tiller \& Cross, supra note 195, at 232 ("Some might fear that the express acknowledgment of political influences in case assignment could undermine respect for the neutrality of judges. This fear, though, rests on delusion. When judges are making ideologically influenced decisions, a myth of neutrality can be sustained for only so long.").

198 We should note that the potential for admitting the political element of judging to strengthen that element provides a plausible objection to our judicial disclosure proposal discussed supra Part IV.B.

199 Adoption of this proposal would require legislative action as, under current law applicable to all circuit courts except the Federal Circuit, except where a majority of a court approves en banc proceedings, "[c]ases and controversies shall be heard and determined by a court or panel of not more than three judges." 28 U.S.C. $\S 46$ (c) (2006). The Federal Circuit has authority to create larger panels by rule. Id. 
to a six-Democrat/five-Republican split on the Second Circuit to a sixteenDemocrat/ten-Republican split on the Ninth Circuit. ${ }^{200}$ Even for a quitelopsided pool, however, the effect of increasing panel size can be substantial. For instance, in a hypothetical Twelfth Circuit composed of nothing but ten Republicans, increasing panel size for the court would not reduce the likelihood that a random draw of judges would produce an unmixed panel--this likelihood would remain 100 percent. Add just one Democrat to the mix, however, and the likelihood of randomly selecting a threeRepublican panel is about 73 percent; increase panel size to five judges, and this likelihood drops to about 55 percent. ${ }^{201}$

Given its role in administrative law, the single most important court to consider is naturally the D.C. Circuit. Though not so bad off as our hypothetical Twelfth Circuit, this court has one of the more lopsided partisan mixes for active judges, with three Democrats and six Republicans. ${ }^{202}$ Its roster of senior judges is also lopsided-one Democrat and four Republicans. To make the math a bit easier while still illustrating the point, assume that three of the four Republican senior judges feel like hearing cases in any given month but that the single senior Democratic judge never participates. Assume also that, for each month that the court hears cases, the Clerk of Court assembles four merits panels from the available judges (three Democrats and nine Republicans) by dealing a deck of twelve cards with three Ds and nine Rs into four hands of three. ${ }^{203}$ The Ds and Rs in the deck can be

200 For a list of active judges and dates of appointment from the official websites of these circuits, see Eighth Circuit Court of Appeals Judges, U.S. CT. APPEALS FOR EIGHTH CIRCUIT, http://www.ca8.uscourts.gov/newcoa/judge.htm (last visited Nov. 4, 2011 ); Second Circuit Judges, U.S. CT. APPEALS FOR SECOND CIRCUIT, http://www.ca2.uscourts.gov/judgesmain.htm (last visited Nov. 4, 2011); The Judges of this Court in Order of Seniority, U.S. CT. APPEALS FOR NINTH CIRCUIT, http://www.ca9.uscourts.gov/content/view_seniority_list.php?pk_id=0000000035 (last visited Nov. 4, 2011).

201 If a clerk assembles a panel by putting all eleven judges' names into a hat and drawing three out, then the chance of assembling a three-R panel would be: $10 / 11 \cdot 9 / 10 \cdot 8 / 9=8 / 11$, which approximates to 0.73 . The chance of assembling a five-R panel would be $10 / 11 \cdot 9 / 10 \cdot 8 / 9 \cdot 7 / 8 \cdot 6 / 7=6 / 11$, which approximates to 0.55 .

202 For a list of D.C. Circuit judges from the court's official website, see Judges, U.S. CT. APPEALS FOR D.C. CIRCUIT, http://www.cadc.uscourts.gov/internet/home.nsf/content/judges (last visited Nov. 4 , 2011).

203 Some courts assign panels on this type of random, month-by-month basis. See, e.g., Internal Operating Procedures, U.S. CT. APPEALS FOR FED. CIRCUIT 3 (2008), available at http://www.cafc. uscourts.gov/images/stories/rules-of-practice/IOP.pdf ("The clerk's office runs a computer program that randomly generates three-judge panels for each month, subject to the judges' availability.”). The D.C. Circuit's process is actually more complex, as the Clerk of Court "attempts to pair each active judge with each other active judge an equal number of weeks during the year, insofar as availability permits." Handbook of Practice and Internal Procedures, U.S. CT. APPEALS FOR D.C. CIRCUIT 46 (2011), available at http:/www.cadc.uscourts.gov/internet/home.nsf/Content/VL\%20-\%20RPP\%20-\%20Handbook $\% 202006 \% 20$ Rev\%202007/\$FILE/handbook20091201 rev20091 106.pdf. For a discussion of procedures for assembling panels across the federal circuit courts (and their departures from random selection), see 
dealt into 220 distinct arrangements, ${ }^{204}$ each of which contains four hands, for a total of 880 potential hands. Of these hands, four of 880 are D-D-D; 336 of 880 are R-R-R; and 540 of 880 are mixed. ${ }^{205}$ Dropping the card metaphor, the likelihood of encountering a panel from one party under these circumstances is $340 / 880$ or 0.386 - with $\mathrm{R}-\mathrm{R}-\mathrm{R}$ being eighty-four times more likely than D-D-D.

Suppose, however, that for some especially significant and welldefined categories of administrative action, the Clerk assembles a special panel of five judges taken from the same pool. The Clerk puts the judges' names into a hat and then pulls them out one by one. There is no chance of assembling a panel of five Ds because there are only three Ds in the pool. At the start, there are nine $R s$ in the hat, leaving a nine-out-of-twelve chance $(0.75)$ of pulling an $\mathrm{R}$ as the first name. If this occurs, then eight of the remaining eleven names will be $R s$, leaving an $8 / 11$ chance $(0.727)$ of pulling an $\mathrm{R}$ as the second judge for the panel. Carrying this exercise out to

J. Robert Brown, Jr. \& Allison Herren Lee, Neutral Assignment of Judges at the Court of Appeals, 78 TEX. L. REV. 1037, 1069-78 \& tbl.1 (2000).

204 See Morris H. DeGroot \& MARK J. SChERvish, Probability and STATISTICS 28-30 (3d ed. 2002) (explaining that $n$ total items composed of two distinct types-for example, $k$ red balls and $n-k$ green balls-can be arranged in $n ! /(k !(n-k) !)$ ways). Nine Rs and three Ds in the pool sum to an $n$ of twelve; $k$ represents the number of Rs, and $n-k$ represents the number of Ds (12-9=3). As such, the judges can be arranged in $12 ! /(9 !(3 !))$ ways, which equals 220 .

205 Determining the number of potential D-D-D panels is straightforward. To form such a panel, all three available Ds have to fall in one hand, and there are four available hands; therefore, there are only four potential hands of $D-D-D$ among the 880 hands available. Determining the number of potential $R$ $R-R$ hands is more involved. The Clerk's deal can produce anywhere from one to three hands of R-R-R. (It is impossible to produce zero hands of R-R-R, as there are only three Ds to distribute across four hands.) Working backwards, if the Clerk deals three hands of $R-R-R$, then the remaining hand must be D-D-D. As the D-D-D hand can take four different positions, the Clerk can deal a hand that produces three R-R-R hands in four different ways, for a total of twelve. If the Clerk deals exactly two hands of $R-R-R$, then the remaining two hands must be composed of three Ds and three Rs. These remaining cards can be distributed into $6 ! /(3 !(3 !))=20$ arrangements. Two of these arrangements (D-D-D/R-R-R and R-R-R/D-D-D) have already been counted, however, as these arrangements would produce three $R$ $R-R$ hands. This leaves eighteen distinct arrangements of the six cards that do not produce unanimous hands. We must, however, bear in mind that the two hands of R-R-R can be arranged across any of four spaces in $4 ! /(2 !(2 !))=6$ ways. There are thus $18 \cdot 6=108$ deals of the deck that produce exactly two $R-$ $R-R$ hands, for a total of 216 R-R-R hands. If the Clerk deals exactly one hand of R-R-R, then there must be exactly one $D$ in each of the remaining hands-i.e., each remaining hand is composed of R-R-D in some order. As the D can occupy any space in any of the three hands, there are three possibilities for arranging each of the three hands, which means that there are $3 \cdot 3 \cdot 3=27$ potential arrangements of the three hands. Note, however, that the unanimous R-R-R hand can occupy any of four spaces. Therefore, there are $27 \cdot 4=108$ deals of the deck that can produce exactly one R-R-R hand. The Clerk can thus deal the cards into 336 potential hands of R-R-R and four potential hands of D-D-D of the 880 hands. This means that the likelihood of encountering a unanimous panel is $340 / 880$, which approximates to 0.386; the likelihood of encountering an R-R-R panel is $336 / 880$, which approximates to 0.382 , and the likelihood of encountering a D-D-D panel is $4 / 880$, which approximates to 0.005 . 
its conclusion shows that the chance of assembling an R-R-R-R-R panel equals:

$$
9 / 12 \cdot 8 / 11 \cdot 7 / 10 \cdot 6 / 9 \cdot 5 / 8=0.159
$$

Thus, even with an extremely lopsided court, increasing panel size to five decreased the likelihood of encountering a single-party panel from 0.386 to 0.159 -an approximate 2.5-fold decrease.

Were the pool evenly divided between six Ds and six Rs, the effect of increased panel size would be even more noticeable. Assuming the Clerk constructs three-judge panels by dealing cards as described above, the judges could be dealt into 924 arrangements of Ds and Rs, for a total of 3,696 potential panels. ${ }^{206}$ Of this number, 672 panels would be composed solely of Ds or Rs. ${ }^{207}$ Therefore, the likelihood that a litigant would encounter an unmixed panel would be $672 / 3,696$, or approximately 0.182 . If, however, the Clerk assembles a special five-judge panel by pulling names out of a hat, the chance of encountering a purely partisan panel becomes vanishingly small:

$$
6 / 12 \cdot 5 / 11 \cdot 4 / 10 \cdot 3 / 9 \cdot 2 / 8=0.015
$$

The odds of drawing an unmixed panel from the six-D/six-R pool decrease from 0.182 to 0.015 when panel size is increased from three to five; this represents an approximate twelve-fold decrease.

Of course, one might argue that the problem of purely partisan panels could be more honestly, directly, and effectively addressed by requiring mixed panels of three, rather than taking the indirect route of expanding panel size to five. There is much to be said for diplomatic cover, however.

$20612 ! /(6 !(6 !))=924$ and $924 \cdot 4=3,696$.

207 The Clerk's deal could produce: two R-R-R panels and two D-D-D panels; one R-R-R panel, one D-D-D panel, and two mixed panels; one R-R-R panel, zero D-D-D panels, and three mixed panels; zero R-R-R panels, one D-D-D panel, and three mixed panels; or zero R-R-R panels, zero D-D-D panels, and four mixed panels. There are $4 ! /(2 !(2 !))=6$ arrangements that could produce two $R-R-R$ panels and two D-D-D panels, for a total of twenty-four unanimous panels. If the Clerk deals one R-R-R panel and one D-D-D panel, then the remaining cards can be dealt into $6 ! /(3 !(3 !))=20$ arrangements. Two of these arrangements, however, produce additional unanimous panels and have already been counted, leaving eighteen. Note that the two unanimous and two mixed panels, can be arranged in $4 ! /(2 !(2 !))=6$ ways. This figure must be doubled to take into account that the two unanimous panels can be switched (e.g., R-R-R, D-D-D, R-D-D, D-D-R is distinct from D-D-D, R-R-R, R-D-D, D-D-R). We thus have $18 \cdot 6 \cdot 2=216$ arrangements that yield two unanimous panels each, for a total of 432 .

If the Clerk deals one R-R-R panel and zero D-D-D panels, then each of the three remaining panels must contain one $R$ and two Ds. Within each of three panels, the $R$ can occupy any of three spaces. This yields $3 \cdot 3 \cdot 3=27$ arrangements. As the one R-R-R panel can occupy any of four spaces, this yields 27 - $4=108$ unanimous R-R-R panels. By the same analysis, there are 108 potential D-D-D panels where the Clerk deals exactly one D-D-D panel and zero R-R-R panels. Tallying these figures shows that there are 672 unanimous panels among the 3,696 the Clerk might deal. $672 / 3,696$ approximates to 0.182 . 
Expressly requiring mixed partisan panels by statute would loudly proclaim in the most concrete way imaginable that judges are partisan creatures. Such a frontal assault would likely raise constitutional issues of legislative control over the judiciary as well.

By contrast, by avoiding express reference to judges' partisan affiliations, expanding panel size would avoid direct insult. Moreover, one can make a plausible argument that especially important cases should have larger panels to increase the likelihood of correct results. ${ }^{208}$ Expanding panel size enjoys a kind of plausible deniability that a direct requirement of mixed panels does not. (To help with this plausible deniability, it may help this proposal's prospects if all of its readers swear to never mention it to anyone).

Another objection is the absence of evidence that the moderating effect of mixed three-judge panels (two-to-one) would necessarily apply to mixed five-judge panels (three-to-two or four-to-one). Certainly, we know that under some circumstances, larger mixed panels do not avoid politicization-the Supreme Court's infamous five-to-four conservative-liberal split demonstrates this point. ${ }^{209}$

A definitive response to this objection is not possible because we do not fully understand why the mixed-panel effect exists, even for three-judge panels where the two-judge majority can theoretically outvote a lone dissenter. As discussed earlier, this may be the product of the potential for whistle blowing or the collegial, internal dynamics of panels. ${ }^{210}$ At first glance, there seems little reason to think that these mechanisms would not affect five-judge-panel behavior as well. A one- or two-judge minority on a five-judge panel can provide opposing views and arguments as well as a one-judge minority on a three-judge panel can. Also, a one- or two-judge minority on a five-judge panel can write dissents and blow whistles.

The proposed mechanisms underlying mixed-panel effects also suggest that the Supreme Court's behavior does not shed much light how fivejudge panels would behave. Most obviously, because it is, after all, "Supreme," the high court is not subject to the same type of whistleblower effects observed at the circuit court level. Moreover, collegiality functions differently at the Court given that all nine justices sit together for almost every case; they expect to split sharply on any case having ideological import; and the cost of dissent is low, given the low number of cases the justices hear and their fleets of hypercompetent clerks.

208 See Philip J. Boland, Majority Systems and the Condorcet Jury Theorem, 38 STATISTICIAN 181, 182,185 (1989) (explaining that, where votes are independent and each voter is more likely than not to vote correctly, increasing the size of a jury increases the likelihood of a correct result and further noting that refined versions of the theorem have relaxed the requirement of independence).

209 Cf. Pierce, supra note 159, at 90 (observing that the Supreme Court's behavior indicates that the panel "effect seems to disappear when the number of decisionmakers increased from three to nine").

210 See supra text accompanying notes $85-91$ and $97-100$. 
In sum, increasing panel size from three to five for a well-defined category of administrative law cases (e.g., petitions for review of legislative rules with significant economic effects) would sharply reduce the presence of unanimously partisan appellate panels. Mixed panels, whether R-R-D or $\mathrm{D}-\mathrm{D}-\mathrm{R}$, behave in a less ideological manner than purely partisan panels do. There is little reason to think that this mixed-panel effect would not translate (at least, in large part) from a three-judge to a five-judge setting. Expanding panel size thus provides a means to depoliticize administrative law-and it does so in a way that would be much less antagonistic to judicial traditions and to judges than directly imposing a statutory requirement of mixed panels.

\section{CONCLUSION}

The old saw about dermatology is that it is a great business because patients never die, and they never get better. There is a similar dynamic in administrative law - it will always be with us, and it will always be messy because of the nature of the problems it confronts. One of these problems is of the "who watches the watchers" variety. More specifically, American administrative law confronts the problem of politicized judicial review. This problem will never be completely "solved" given that federal judges (especially justices) are picked through a highly politicized process that often borders on theatre of the absurd. These same political judges swear during their confirmation hearings to never let their personal political and policy preferences influence their decisions. The review process later requires them to apply highly indeterminate law as they evaluate the actions of politicized agencies that wield immense discretionary powers over social policy. All of the prominent models of judicial decisionmaking tell us to expect the judges' ideological preferences to affect outcomes when such indeterminacy exists. Given this much, one should not be shocked by the mounting empirical evidence that suggests that, by any reasonable accounting, judicial ideology plays an important role in administrative law.

We recognize that trying to depoliticize administrative law partakes of tilting at windmills. Nonetheless, this Article discusses three possibilitiesone bad, one highly speculative, and one rather promising. Consistent with the teachings of the strategic, craft, and cultural cognition models that law matters to judges, the first and worst possibility is that Congress or the courts themselves could make administrative law more determinate. This move would constrain the scope of judicial discretion and, thus, also limit the available space for judicial ideology to affect outcomes. Neither Congress nor the courts are likely to take this step. Moreover, for a host of sound reasons, ${ }^{211}$ it is not obvious that they should do so.

\footnotetext{
211 See supra Part IV.A.
} 
The second, most speculative possibility takes part of its inspiration from the craft model's focus on judicial professionalism and pride. It suggests that judges adopt a new craft norm of opinion writing that requires them to state their own policy preferences and reactions in the course of reviewing administrative action. Bringing the "inevitable factor" of judicial policy impulses to light in this way would make the judicial review process more honest and transparent. It might also encourage self-criticism and a measure of "debiasing" among judges. On the other hand, giving judicial policy preferences such pride of place might tend to entrench and legitimize them.

Unlike the first two possibilities, our third and most plausible one does not contemplate major changes either to the fundamental character of administrative law or to the norms of judging. Instead, it requires only a (relatively) minor institutional tweak, one inspired by recent empirical research demonstrating that politically mixed judicial panels behave in a lesspartisan manner than politically unmixed panels do. Expanding appellate panels reviewing agency action from three to five judges for a well-defined category of administrative law cases would, as a matter of simple probabilities, greatly reduce the incidence of unanimously partisan panels. Lessening the chance of unmixed panels might in turn go a long way toward lessening the problem of politicized judicial review. 